\title{
WORK-RELATED MIGRATION AND POVERTY REDUCTION IN NEPAL
}

\author{
Michael Lokshin, Mikhail Bontch-Osmolovski, Elena Glinskaya ${ }^{1}$ \\ The World Bank, 1818 H Street NW, \\ Washington DC, 20433 USA
}

\begin{abstract}
Using two rounds of nationally representative household survey data, in this study, we measure the impact on poverty in Nepal of local and international migration for work. We apply an instrumental variable approach to deal with nonrandom selection of migrants and simulate various scenarios for the different levels of work-related migration, comparing observed and counterfactual household expenditure distribution. Our results indicate that one-fifth of the poverty reduction in Nepal occurring between 1995 and 2004 can be attributed to higher levels of work-related migration and remittances sent home. We also show that while the increase in international work-related migration was the leading cause of this poverty reduction, domestic migration also played an important role. Our findings demonstrate that strategies for economic growth and poverty reduction in Nepal should consider aspects of the dynamics of domestic and international migration.
\end{abstract}

Keywords: migration, remittances, poverty measurement, Nepal

JEL: I31, O15, F22

World Bank Policy Research Working Paper 4231, May 2007

The Policy Research Working Paper Series disseminates the findings of work in progress to encourage the exchange of ideas about development issues. An objective of the series is to get the findings out quickly, even if the presentations are less than fully polished. The papers carry the names of the authors and should be cited accordingly. The findings, interpretations, and conclusions expressed in this paper are entirely those of the authors. They do not necessarily represent the view of the World Bank, its Executive Directors, or the countries they represent. Policy Research Working Papers are available online at http:/lecon.worldbank.org.

${ }^{1}$ Corresponding author: Michael Lokshin, mlokshin@worldbank.org, DECRG; Mikhail BontchOsmolovski, misha.bonch@gmail.com, DECRG and University of North Carolina at Chapel Hill, Elena Glinskaya, eglinskaya@worldbank.org, SASPR. All at the World Bank, 1818 H Street, NW, Washington DC, 20433, MSN MC3-306

For their comments, the authors are grateful to Martin Ravallion, David McKenzie, Jed Friedman, Jerro Carletto, Alan de Brauw, Karen Macours, and Toan Do. Special thanks to Pedro Carneiro for his help with the simulation methodology. We also thank Dilip Parajuli for his help with the 2001 Nepal Census data. 


\section{Introduction}

With an average per capita GDP of about $\$ 240$ ( $\$ 1,420$ in purchasing power parity), Nepal is the poorest country of South Asia. About 42 percent of the Nepali population lived on income below the poverty line in 1995-96, 46 percent of the adult population remains illiterate (Central Bureau of Statistics 2003), and almost half the children five years and under are malnourished (Nepal Ministry of Health 2002). During the period of stabilization and liberalization in the mid-1980s and early 1990s, the Nepali economy grew at about 5 percent per year. The impact of these relatively high rates of economic growth on improvements in living standards was dampened by the country's high population and urban-centered growth, limited access to basic services, poor governance, and increasing political instability. Economic growth slowed in the early 2000s due to a global economic slowdown, diminishing export markets, and the escalation of violence resulting in declaration of the state of emergency.

Despite these negative trends, the overall poverty rate in Nepal declined to about 30 percent by the end of 2003. Between 1995 and 2004, real per capita expenditures grew by more than 40 percent in real terms (The World Bank 2005). That growth in per capita expenditure was accompanied by increasing income inequality, as indicated by the Gini coefficient, which climbed from 0.34 in 1995 to 0.44 in 2004 . The country's balance of payments increased to 9 billion Nepalese rupees (NPR) and foreign currency reserves reached NPR 75 billion. The common explanation for these developments, both in the press and among local and international scholars, is the sharp increase in remittances from Nepali expatriates working abroad.

Work migration and remittances, along with the higher agricultural growth, are usually considered the key factors behind declining poverty in Nepal since 1996. Indeed, more than a million prime-age (mostly male) adults are currently working outside Nepal. Remittances from expatriates grew at 30 percent per year and from less than 3 percent of GDP in 1995 to about 15 percent by the end of 2003 (World Bank 2004), exceeding the combined share of tourism, foreign aid, and exports. According to official government statistics, about 1 billion dollars comes into the country as remittances, and inflows through private and unofficial channels could be even larger (Thieme 2003). 
Remittances affect economy-wide resource allocation. At the macro level, inflation, exchange, and interest rates are determined by the amount of money coming into the country in the form of remittances (for example, Djajic 1986). Distributional implications of remittances affect the country's rate of economic growth. At the household level, remittances provide a means of achieving consumption smoothing (Yang and Choi 2005) and mutual insurance (Stark and Lucas 1988), as well as alleviating liquidity constraints (Taylor and Rozelee 2003). Household decisions about the labor market activities of household members, investments in human and physical capital, fertility, and migration also depend on the amount of remittances the household receives (Rapoport and Docquier 2004).

While a large body of literature on international migration exists, the empirical research of the impacts of work-related migration and remittances on poverty and inequality is limited. A macro-level study of 74 low- and middle-income countries by Adams and Page (2003) find that remittances have strong poverty-reducing impact. Adams $(1989,1991)$ presents micro-evidence on the importance of remittances for poverty reduction in rural Egypt, while Adams (2005) summarizes the results of microlevel analysis in several countries, finding that poverty reduction in Bangladesh, Ghana, and Uganda could be attributed to the effects of remittances. Gustafsson and Makonnen (1993) report that completely removing remittances in Lesotho would raise the poverty rate from 52 to 63 percent, and Barham and Boucher (1998), in examining the net effects of migration and remittances on income distribution in Nicaragua, find that migration and remittances increase average household income and income inequality when compared with the no-migration counterfactuals. Yang, Park, and Wang (2005) studied the effects of migration and remittances on poverty in China, finding that without migration and remittances the aggregate poverty rate would increase from 14.4 to 15.4 percent. Other recent papers by McKenzie and Rapoport (2005) and McKenzie et al. (2006) estimate the overall impact of remittances on income distribution in Mexico taking into account their direct and indirect effects on receiving households and the spillover effects on neighboring communities.

The growing numbers of domestic and international migrants who secure work and send remittances back home have a profound effect on many socioeconomic, 
demographic, and political issues in Nepal. It is surprising how little is known about the economic effects of the country's work-related migration and remittances, given the interest in the subject by the Nepali government and international development agencies involved in the country. We are unaware of any research that formally investigates the micro-level relationship between work-related migration and household well-being in Nepal. A few, mostly descriptive, studies by Nepali scholars establish no causal relationship between work-related migration, remittances, and poverty (for example, Acharya 2001 and Chhetry 1999, 2002; see also Kumar 2003). With this paper, the intention is to fill this gap by providing empirical evidence of the effect of migration and remittances on poverty in Nepal.

In this endeavor, we rely on two rounds of the nationally representative household surveys to measure the impact of increased work-related migration and remittance inflows on the economic well-being of Nepali households between 1995 and 2004. More specifically, we model the effect of remittances and work migration on household consumption and aggregate poverty and inequality rates. Using the cross-sectional sample of 2004, we estimate a model of household migration decisions jointly with the consumption equations by the method of full information maximum likelihood (FIML). The method takes into account unobserved household characteristics that could simultaneously affect household migration decisions and household income. We also simulate counterfactual expenditure distributions to determine the effect of work-related migration on poverty and inequality in Nepal.

The results of our estimations show that the increase in the number of working migrants during the past decade had a significant impact on poverty in Nepal. Almost 20 percent of the decline in poverty in Nepal between 1995 and 2004 can be attributed to increased work-related migration and remittance inflows. If the level of migration and the amount of remittances remained at the 1995 level, the poverty rate in Nepal would increase from the currently observed 30 percent to 32 percent; the mean per capita expenditure would decline from about 15,000 to 14,000 NPR. Almost two-thirds of this increase in poverty can be explained by the higher number of the would-be-poor among the households with international migrants. Work-related migration and remittances, however, have only marginal impact of the changes in income inequality in Nepal. 


\section{Data and Measures}

The analysis in this paper is based on the data from two rounds of the Nepal Living Standard Survey (NLSS). The NLSS is a nationally representative survey of households and communities conducted between June 1995 and June 1996 (NLSS-I) and April 2003 and April 2004 (NLSS-II) by the Nepal Central Bureau of Statistics with the assistance of the World Bank. Both rounds use similar modules to collect data on the household consumption of a wide range of food and nonfood items. The survey's instruments also gather detailed information about the demographic composition of the interviewed households, the labor status of the household members, their health and educational achievements, and various sources of household income, including income in-kind, individual wages, and remittance and transfers received in the year preceding the survey.

The NLSS-II sample includes both cross-sectional and panel components. The cross-sectional sample was constructed using a two-stage design based on the 2001 Nepal Census sample. The survey's sample covers 73 districts of Nepal (excluding the Rasuwa and Mustang districts). The NLSS-I sample includes information on 3,373 households in 274 PSUs, while the NLSS-II sample is based on 326 cross-sectional and 95 panel PSUs enumerating 3,912 and 1,160 households, respectively. ${ }^{2}$

We use total per capita consumption expenditure as an indicator of household welfare. Our consumption aggregate includes monthly household expenditures on food and nonfood items, imputed housing expenditures, an imputed stream of services from durables goods, as well as cash expenditures and imputed expenditures for goods and services produced by the household itself. The values of home-produced items are calculated as a product of the quantity of each food item and its prevailing local market price. The poverty line for the analysis is constructed using cost-of-basic-needs approach. To assure comparability over time and across the regions, all monetary indicators (household consumption, values of remittances, wages, and so on) are deflated to 2004 all Nepal prices. The cost of the poverty basket in 2004 all Nepal prices equals NPR 7,694 per year per person - equivalent to US\$107 or US\$590 in PPP (World Bank 2006).

\footnotetext{
${ }^{2}$ For a detailed description of the sample frame and the survey methodology see Central Bureau of Statistics (2006).
} 
A serious data limitation is that households with migrants can only be identified if they reported receiving remittances in the previous year. Three groups of households could be misclassified under this definition. The first group consists of households with migrants who send no remittances. These could be households with a migrant who has just departed and is in the process of establishing him or herself, or households where a migrant brings the remittances home rather than sending them. The second group comprises households that receive remittances but do not report them. Such households might be afraid of revealing information on remittances because of the tax consequences or simply due to concerns for personal safety. Finally, some households could receive remittances from individuals who are not household members. Classifying the households in these three groups as having no migrants would result in biased estimates of the impact of work-related migration on household consumption. Although the direction of the bias is unclear a priori, the size of the bias is proportional to the sizes of these three groups of households.

To assess the extent of such misclassifications, we compare the proportion of migrants in the total population from the 2001 Nepal Census with the proportion of households with remittances in the NLSS data. The proportion of domestic migrants in the 2001 Census (4.8 percent) is statistically close to the proportion of migrants from households receiving domestic remittances in the NLSS (5 percent). The censuscalculated proportion of households with international migrants (14 percent) is lower than the reported NLSS proportion of household receiving remittances from abroad (18 percent). The official statistics report about 1,000,000 prime-age male expatriates working outside Nepal. The equivalent NLSS figure is about 900,000. These relatively small discrepancies indicate that the bias resulting from misclassified households would most likely also be small. More importantly, these results make it feasible to extrapolate inferences about the effects of work-related migration on income distribution from sample households receiving remittances to those in the general Nepali population. 


\section{Migration and Remittances in Nepal: Descriptive Analysis}

The history of foreign employment in Nepal dates back almost 200 years, when Britain began recruiting men from the hillsides of Nepal, known as Gorkhas into the British armed forces. After India's independence in 1947, the Indian military also began enlisting Nepali men. Currently, about 3,500 Nepali solders serve in the British army and more than 50,000 Nepalese are enlisted in the Indian military. India was the first country to attract civilian migrants from Nepal. The inflow of working migrants to India has increased sharply since the 1950s and 1960s, and India now represents the largest market for migration to foreign countries in Nepal (Sheddon 2005). ${ }^{3}$

The Foreign Employment Act of 1985 was the first legislative document to officially recognize the benefits of international migration (Jha 1999). Around that time, foreign labor migration from Nepal extended from India to the countries of the Southeast and Far East, and later to Arab Gulf States. The total number of Nepali migrants working abroad reached 750,000 in 1997, contributing about NPR 35 billion to the country's economy in form of remittances (Sheddon, Gurung, and Adhikari 2000). The reform of the administrative system during 2000 and 2001 resulted in a significant boost in both domestic and international migration. Before the reforms, passports could only be obtained in the country's capital, but under the new regulations, district offices were given the authority to issue passports and other travel documents (McKenzie 2006).

Domestic migration has increased in Nepal since the success of government's efforts to control endemic malaria in the Terai in early 1950s. The inter-district migration constitutes 13.2 percent of domestic migration (Central Bureau of Statistics 2003), while rural-urban migration represents 25.5 percent; rural-to-rural migration, however, is significantly higher, at 68.2 percent. The poor rural regions of the mid- and far-west underwent a net out-migration, with migrants moving from the mountainous and hillside areas to the plains and urban areas. These regions were also the most affected by the Maoists insurgency over the past 10 years (Do and Iyer 2007). In the Katmandu valley and other urban areas, and in the Terai region, inflows of migrants surpass outflows.

\footnotetext{
${ }^{3}$ The "Treaty of Peace and Friendship" signed by the Indian and Nepali governments in 1950 allowed Nepali nationals to enter and work in India without a visa and any job restrictions (Thapliyal 1999).
} 
The NLSS is the first and only data source to provide statistically accurate estimates of levels of and trends in international work-related migration from Nepal and on the amount of money sent home in remittances. According to NLSS, 23 percent of households in Nepal received remittances in 1995, and that proportion climbed to about 32 percent in 2004. Further, the share of households with remittances from abroad grew from 10 to 17 percent between the survey's two rounds. The amount of remittances also increased from about NPR 22,000, or 36 percent of mean household yearly consumption expenditure in 1995, to NPR 35,000 or 44 percent of mean expenditure in 2004.

Figure 1 shows the incidence and the amount of remittances by household size for 1995 and 2004. ${ }^{4}$ Focusing first on the top panel of the graph, the proportion of households receiving remittances grows monotonically with household size. For example, in 2004 only about 10 percent of households with two or three members received money from abroad, while that proportion is more than three times higher for households with 11 or more members. The changes in the amounts of remittances by household size are shown on the lower panel of the graph. The plot indicates that in 1995 households with different sizes received almost the same amount of money, while the 2004 data show that remittances increase with household size.

The incidence of remittances is higher in rural than in urban Nepal. The proportion of households receiving remittances from within the country increased only marginally between 1995 and 2004, and even declined in Kathmandu (top section of Table 1). At the same time, the share of households receiving money from abroad increased uniformly across the country. For example, the rural eastern hills-the poorest region in Nepal-registered a fourfold increase in the number of households receiving money from abroad; that proportion more than doubled in "other urban areas" of Nepal. Thus, the overall increase in the proportion of households with remittances could almost entirely be attributed to the growth of remittances from abroad. There is no clear pattern in the distribution of the household recipients of the remittances by the size of landholdings. The largest increase in the incidence of both domestic and international remittances is registered among households with two and more hectares of land.

\footnotetext{
4 The size of households with migrants was adjusted for the missing migrant members.
} 
Looking at the proportions of households receiving remittances by caste (bottom part of Table 1), Dalit households have the highest probability of receiving money from outside Nepal (25 percent), while the incidence of external remittances is much lower among Newars and Terai Janjatis. At the same time, only 10 percent of Dalit households receive remittances from Nepal. This might suggest that poor job opportunities at home prompt Dalit households to concentrate their job search efforts abroad.

Individual profiles constructed using NLSS data reveal that almost all international migrants are male (97 percent) aged 15 to 44 years, and either sons or husbands of the person receiving remittances. Brothers represent about 10 percent of the total number of donors. In 1995, 85 percent of Nepali migrants worked in India, and the rest were spread among Malaysia (11 percent), Bhutan, and Hong Kong. As of 2004, international migrants were living in 10 countries: 65 percent worked in India, 18 percent in Arab countries, and about 2 percent in United Kingdom, while some migrants lived as far away as Japan and the United States. Remittances from abroad constituted 76 percent of the total amount of remittances received in Nepal in 2004. The largest share of international remittances came from Saudi Arabia, Qatar, and the United Arab Emirates (35 percent), followed by 30 percent from India, 17 percent from other Asian countries, and the remainder from United Kingdom, United States, and other countries.

The correlations between household income and the incidence and amount of remittances are shown in Figure 2. The main difficulty in illustrating this relationship is that current income is endogenous to the remittances. We attempt to address this problem by constructing a two-year-lagged asset index to proxy for pre-migration income. ${ }^{5}$ Overall, the incidence of remittances (or migration) is higher among (asset) poor households. It reaches 44 percent for the poorest households in Nepal and declines monotonically to about 10 percent for the richest households. The correlation between the amount of remittances and household wealth goes in the opposite direction. Households with the highest lagged asset index receive significantly larger amounts of money from working migrants than do poor households. These results, however, could indicate that

\footnotetext{
${ }^{5}$ The lagged asset index was constructed based on the estimated cash value of the flow of services provided by the durable goods. In our calculations, we included only durable assets purchased by households at least two years prior the date of the survey (2001 and older). In justifying the exogeneity of the lagged asset index, the fact that the major increase in work migration in Nepal was initiated by the reforms of the administrative system of 2001 was taken into consideration (see Section 3).
} 
households receiving the largest remittances have been receiving them for a long time, resulting in an accumulation of durable assets (Stark 1978).

\section{Work-Related Migration and Poverty: Theoretical Considerations and Empirical Specification}

Remittances sent home are the most tangible benefit of work-related migration for Nepali households. On the production side, remittances enable households to overcome the constraints of credit and risk on their ability to engage into modern and more productive activities (Stark 1991). Remittances can be spent on housing and schooling, and a significant proportion directly supports household consumption. But remittances are only one of the consequences of migration. When a young, able, and productive male household member leaves home, multiple adjustments need to be made among those left behind. Migration changes the relative productivity of the remaining household members; affects household preferences in terms of risk aversion and uncertainty; and provides new information - for example, on new technology, type of crops, and so on. Women who previously worked in the labor market may find it optimal to stop working and devote all their time to home production (Nandini 1999). Agricultural households might decide to augment their income with off-farm activities. Migration also has implications for the health and educational attainment of the migrant's children (Hilderbrandt and McKenzie 2004; McKenzie and Rapoport 2005).

The observed consumption behavior and poverty status of the household receiving remittances are determined by the cumulative effects of all these changes. Finding valid instruments to disentangle the effect of remittances from the overall impact of migration on household well-being can be problematic. Even if such instruments exist, the question of the effect of migration on household well-being has more policy relevance than a narrower question focusing only on the effect of remittances. The goal of this study is to analyze the impact of work-related migration and remittances on the consumption of households at home and to estimate the effects of work-related migration on aggregate poverty and inequality in Nepal. As in any impact assessment, the welfare impact of work-related migration should be judged relative to the counterfactual of what have been 
observed in its absence. In particular, we model how the observed income distribution compares to the counterfactual distribution without migration or remittances.

Our theoretical framework relies on several assumptions. First, we assume that households have a choice to send a migrant to work within Nepal or abroad. This assumption imposes certain restrictions on the sample for empirical estimations. We also assume that migration has to be planned ahead. Before the migration takes place, multiple arrangements need to be made. If traveling abroad, a Nepali migrant has to apply for and obtain a visa, get an international passport, and purchase a ticket. And a migrant's household incurs expenses in the form of migration broker fees and traveling costs (Bhattarai 2005). ${ }^{6}$ This preparation process could take several years depending on the country of destination. This assumption is crucial for our identification strategy.

Consider a simple two-period model of household utility maximization. ${ }^{7}$ In time period 1, a household decides that one of its members will migrate. This involves three possible states: migration abroad, migration within Nepal, and no migration. Each state has an associated cost for a household. Such costs could, in case of migration, include transportation costs, visa and document processing fees, money to cover initial expenses, and so on. To decide whether to embark on migration or not, a household compares its expected net benefits in each state (in period 2) and selects the state with a highest utility payoff. Households observe the realized labor market outcomes in time period 2: once settled in the new location, migrants inform households about their wages and local market conditions become known. With this information, households make decisions about member participation and market work hours and investment, adjusting their consumption level accordingly.

In the simplest form, a household chooses between two states: to send or not send a household member to work in another location, whether locally or abroad. Let $U$ be the household utility function which depends on household consumption $\left(\mathrm{C}_{t}\right)$ and the household characteristics $X_{t}$ in period $t(t=0,1)$. The household income $Y_{t}$ comprises both wage and nonwage income, as well as income from home-production. $R$ is the expected

\footnotetext{
${ }^{6}$ Fees to obtain travel documents, such as entry and identity cards charged by intermediaries vary by country and could be as high as US\$15,000 (Yamanaka 2000).

${ }^{7}$ Several studies provide strong support for the argument that migration is a household utility maximization decision (for example, Stark and Levhari 1982 Low 1986; Hoddinott 1994; Agesa and Kim 2001;

Bhattacharyya 2005;).
} 
benefits of migration (which could be both positive and negative, including remittances and other consequences of migration). Let $z$ define a set of regional factors affecting the cost of migration $P\left(X_{0}, z_{0}\right)\left(P_{z}^{\prime}<0\right)$ assumed at period 0 . Both $P$ and $R$ are equal to zero in the case of no migration. The maximization of the household utility function can then be expressed in the form:

$$
\operatorname{Max}\left[U\left(Y_{1}\left(X_{1}\right)+R\left(X_{1}\right)\right)+U\left(Y_{0}\left(X_{0}\right)-P\left(X_{0}, z_{0}\right)\right), U\left(Y_{1}\left(X_{1}\right)\right)+U\left(Y_{0}\left(X_{0}\right)\right)\right]
$$

The first term in parenthesis is the household's indirect utility if it decides to proceed with migration, and the second term is the indirect utility in the case of no migration. The obvious predictions from this model are that the reduction in the cost of migration, $P$, and the higher expected returns from migration increase the probability of a household choosing to send a migrant. This simple specification can be extended to cases with more than two states of migration. We allow for three states of migration: international migration, migration inside Nepal, and no migration.

We assume that utility of a household in state $s$ can be linearly approximated as

$$
U_{i s}=X_{i} \gamma_{s}+Z_{i} \varsigma_{s}+\eta_{i s}, s=1,2,3
$$

where $Z_{i}$ is the vector of household characteristics that includes both $X_{i}$ and $z_{i}, \gamma$ and $\varsigma$ are vectors of unknown parameters, $s$ is an indicator describing household migration choice, and $\eta_{i \bullet}$ 's are the error terms. The household selects the migration state $s$ if

$$
U_{i s}>\max \left(U_{i j}\right)_{j \neq s}, s=1,2,3
$$

Consumption $C_{i s}$ in a particular state is observed only if that state is chosen:

$$
C_{i s}=\beta_{s} X_{i}+\mu_{i s}, s=1,2,3 \text { if } U_{i s}>\max \left(U_{i j}\right)_{j \neq s}
$$

where $X_{i}$ is a vector of explanatory variables that determine the household consumption level, $\boldsymbol{\beta}_{s}$ is a vector of parameters, and $\mu_{i}$ 's are the error terms.

The estimation of equation (4) in three states (migration abroad, migration within Nepal, and no migration) using ordinary least squares (OLS) enables inferences to be made about the returns to the observed household characteristics in each state under the assumption that the error terms in equations (2) and (4) are independent- that is, if we assume no systematic unobserved differences in household characteristics by migration state. Then it is possible to predict the counterfactual consumption levels for households in the sample if international, internal or no migration decisions have been made. The 
probability of a household choosing migration state $s$ could be estimated by a standard multi-nomial model. The inferences about the aggregate impact of work migration on poverty and inequality might also be obtained (see, for example, Adams 1991, 2005 and Taylor and Wyatt 1996).

However, some unobserved household and/or potential migrant characteristics could affect both the household's decision to migrate and the household's consumption. ${ }^{8}$ For example, it might be optimal for a household to send a member with high entrepreneurial abilities abroad. These abilities, which are usually unobserved by a researcher, could also allow a migrant to earn higher wages in comparison with the average migrant worker and send more money back home. The challenge for our empirical strategy is to estimate the system of equations (2)-(4) controlling for such unobserved factors.

Being incorporated into the error terms in equations (2) and (4), the unobserved factors can be correlated. If error terms $\mu$ 's and $\eta$ 's are not independent, the nonrandom selection of households into different states will result in a correlation between the explanatory variables $X$ and errors $\mu$ 's in equation (4). In that case, the OLS estimates of consumption equation (4) are biased. To obtain unbiased and consistent parameter estimates under an assumption of joint dependence of the error terms, we use the method of full information maximum likelihood (FIML). The method estimates the household consumption equations jointly with the equation describing the household choice of migration state allowing for the correlation of the error terms across equations. The detailed discussion of our estimation methodology is shown in Appendix 1.

To estimate the impact of remittances and migration on poverty and inequality in Nepal, we simulate the counterfactual expenditure distributions under different migration scenarios. The FIML estimation of equations (2)-(4) identifies the parameters of fivevariate distribution of the error terms. The observed outcomes of the migration decision

\footnotetext{
${ }^{8}$ Migrant selection was studied by Chiswick (1978), and Borjas (1987, 1990, 1991) developed a model of self-selection based on unobserved migrant characteristics. The problem of self-selection of migrants was also studied by Docquier and Rapoport (1998), Aydemir (2003) and Kanbur and Rapoport, (2005). Barham and Boucher (1998) build their model on the assumptions of potential endogeneity of household's migration and labor force participation decisions. A recent study by McKenzie, Gibson, and Stillman (2006) using the survey of the winners of a migration lottery concludes that migrants are positively selected in terms of both observed and unobserved skills.
} 
truncate the joint distribution of consumption for each individual. Though analytical expressions for such truncated distributions are unattainable, we recover the distributions by randomly drawing the error terms from the five-variate truncated normal with 1,000 replications. This way, we generate the simulated universe of 3,620,000 household expenditures with a different realization of conditional errors. The poverty rates and Gini coefficients (or any other statistic) could then be calculated for the particular counterfactual scenario. Confidence intervals for the inequality and poverty measures are estimated by the jackknife method (see Appendix 2 for the detailed description of the simulation technique).

\section{Identification Strategy}

Our theoretical model guides an identification strategy for the empirical estimation. The fact that migration and consumption decisions are separated in time allows us to assume that certain factors (variables) affecting the migration decision in time period 1 have no direct impact on household consumption in period 2. Such variables could be used as instruments in the FIML estimation of equations (2)-(4). A variation in these instrumental variables would identify the causal effects of migration and remittances on household consumption because the effect of this variation is entirely channeled through household migration decision. We use two instruments to identify the separate effects of international and domestic migration on household consumption.

The first instrument, the proportion of migrants in a ward in 2001, is constructed based on information from 2001 Nepal Census (Central Bureau of Statistics 2003). The proportion of households with migrants in a village in 2001 could be interpreted as a proxy for the extent of village-level networks. We argue that 2004 household consumption should not be directly affected by the migration networks in 2001 . Carringon, Detragiache, and Vishwanath (1996) and Munshi (2003) test the role of networks in promoting migration and find a greater propensity toward migration in villages with existing migrants - meaning that there is propensity for new migrants to follow in the footsteps of existing migrants. When in the host country, Nepali migrant workers develop extensive social networks that link them with their relatives and friends 
at home (Yamanaka 2003). Such networks lower the costs of migration for villagers by providing information about job opportunities outside Nepal, helping potential migrants secure employment, supplying credit to cover reallocation expenses, and ameliorating housing costs upon arrival. Indeed, as Thieme (2003) shows, in Nepal, migrants tend to follow their co-villagers and migrate to the same destinations. They are also likely to fill the same niches in the labor market in the host county. Relying on a similar identification strategy, Woodruff and Zenteno (2001) and McKenzie and Rapoport (2005) analyze the effects of migration on children's health and schooling outcomes in Mexico; Du et al. (2005) study the relationship between migration and rural poverty in China; and Taylor and Mora (2006) investigate the effect of migration on expenditure patterns of rural households in Mexico. We expect this instrument to affect the probability of international migration and have small or no influence on the probability of migration within Nepal.

To construct an instrument for the domestic migration, we use data from the first round of the NLSS. The variable for this instrument is the proportion of domestic migrants in a district in $1995 .{ }^{9}$ The underlying rationale is similar to the one discussed above, and we expect this instrument to have a positive and significant effect on the probability of domestic migration.

Our identification strategy requires that lagged migrant networks influence household consumption only through current migration. The presence of ward or district characteristics or shocks that simultaneously influence migration and household consumption decisions would violate our identification restrictions. For example, better road infrastructure in a ward or its proximity to a large urban center could reduce the costs of migration and, at the same time, affect a household's returns on productive activities by providing better access to markets. We endeavor to control for timepersistent unobserved factors by including a set of ward-level characteristics in our empirical specification. In particular, we include variables that specify local labor-market conditions, the occupational structure of the population in a ward, and the set of dummies for aggregated educational levels. In addition, we use the ward-level lagged (1995) mean expenditure and expenditure Gini. These variables describe the lagged regional poverty

\footnotetext{
${ }^{9} \mathrm{We}$ also tried to add the proportion of migrants abroad in a district in 1995 as an instrument. This variable adds no extra identification power to our estimations, most likely because of a low level of variation in foreign migration registered in 1995.
} 
situation and can capture many unobserved factors affecting both the household's migration decision and its current consumption level. Nevertheless, we cannot completely rule out the presence of latent local characteristics that are correlated with our instruments and simultaneously affect household migration and consumption behavior.

We can speculate about the effects of unobservable time-variant characteristics on our results. By having a larger number of households with a migrant worker, locations with extensive migrant networks receive more remittances compared to those with fewer migrants. If invested in the development of local infrastructure, remittances would raise the local capital stock, and that in turn might positively affect residents' current earnings and incomes (see for example, Dustmann and Kirchkamp 2002). Past migration could also influence current consumption through its effect on the local labor market. Higher levels of remittances may increase aggregate demand and hence the demand for labor (Funkhauser 1992). The out-migration of prime-age males might tighten local labor markets, allowing better job opportunities for workers in the home communities.

Both scenarios would lead to a downward bias in our estimates. The consumption levels of nonmigrant households living in locations with more migrants would be positively affected by externalities related to work-related migration and remittances. The counterfactual consumption of a household with a migrant - that is, had that migrant stayed home - would be overestimated because of these externalities, thereby reducing the estimated impact of migration and remittances. In that case, our results would provide lower bounds for the true effect of work-related migration on household consumption.

Our identification strategy relies on the assumption of separability of household's migration and consumption decisions. In our model, households first decide about the work-related migration of its members and then about the household consumption. In the alternative framework of life-cycle maximization with perfect foresight and endogenous migration decision (Mesnard 2004) the exclusion restrictions for our instruments would not be valid. We can argue, however, that the sequential model of household decisionmaking better describes the behavior of households in a highly uncertain political and economic environment of Nepal. 


\section{Explanatory Variables and the Sample for Estimations}

The predictions of the theoretical model determine the choice of our explanatory variables. The descriptive statistics for the main explanatory variables used in our analysis are reported in Table 2 . These variables could be grouped conceptually into two categories. The first group describes factors affecting the household production. These include the household demographics, education of female household members, and variables describing ethnicity. ${ }^{10}$ We also include variables on a lagged household land ownership and lagged asset index as proxies for household wealth. The lagged asset index was constructed based on the estimated cash value of the flow of services provided by the durable goods. In our calculation, we include durable assets purchased by households at least two years prior the date of the survey (2001 and older). We then divided all households in our sample into four groups according to the percentiles of their lagged asset index. The fact that the major increase in migration in Nepal happened after the administrative reform of 2001 (see Section 3) helps to justify the exogeneity of this variable in our model. Our specification also contains a variable on the per capita amount of pensions a household received over the past year. The second group of variables comprises characteristics related to the region and ward.

We restricted our sample to households that actually have or could have a working migrant. We excluded 30 households from the sample because they represented migrants living alone. We also excluded 235 households without migrants whose members were not of working age (that is, children and the elderly). Using the language of impact evaluation, we therefore only estimate the "LATE" effect of work-related migration and remittances on the well-being of Nepali households.

\footnotetext{
${ }^{10}$ The demographic characteristics are adjusted to reflect the pre-migration status of the households. In particular, for households with a migrant, we increased household size by one to account for a migrant member. All shares of members from different age and gender groups are changed accordingly. Because we have no information on a migrant other than his age, we could not include any variables on characteristics of the household head or on other male members.
} 


\section{Results}

The results of the FIML estimation of equations (2)-(4) are shown in Table 3 (discrete part of the model) and Table 4 (continuous part of the model). ${ }^{11}$ Focusing first on the results for the choices of migration states, households living in wards with a historically higher proportion of international migrants are significantly more likely to migrate abroad compared with households without migrants. Households residing in districts with larger shares of domestic migrants are more likely to send their members to work in locations within Nepal. This relationship is consistent with the predictions of our theoretical model and indicates that our instruments have a significant effect on the households' choice of migration status.

Large households and households with a higher proportion of adult women and the elderly are more likely to have a migrant. Compared with Brahman and Chhetri, other castes are less likely to migrate within Nepal, and the Newars appear to prefer not to migrate abroad. Land ownership does not affect the probability or destination of workrelated migration, whether locally or abroad. The probability of a household having a domestic migrant is higher among poorer households compared with wealthier households (based on the percentiles of the lagged asset index). Poor households are also less likely to have members working abroad. At the same time, individuals from both the poorest (those who reported no durables) and the wealthiest households are more likely to work abroad. We might speculate that the members of the wealthy households tend to migrate to Gulf States, while the poorest migrants mainly work in India.

The estimations reveal the expected geographical patterns of migration. Individuals residing in Katmandu are less likely to migrate compared with those living in other areas of Nepal. This could be attributed to better labor market conditions in the country's capital. The probability of international migration is higher among households

\footnotetext{
${ }^{11}$ According to the likelihood-ratio test, the specification that assumes that the error terms in equations (2)(4) are independent is rejected in favor of the FIML estimation. The estimation results of the system of equations (2)-(4) assuming joint independence of the error terms are provided in Appendix 3. Three pairwise tests of the equality of coefficients between the regressions in equation (5) are rejected with at least 0.01 percent significance.

We attempted to estimate the system of equations (2)-(4) using a Semi-Parametric Maximum Likelihood estimator (for example, Mroz 1999), which relaxes the assumption of joint normality of the error terms in these equations. However, we were unable to achieve convergence even with the minimal number of points of support. For that reason, we reverted to the more restrictive FIML estimator.
} 
from the rural western mountains and hills. Households in wards with a higher proportion of illiterate residents are less likely to have a member migrate to locations within Nepal, and households in the wards with a large share of self-employed residents are more likely to have members migrate for work within Nepal.

Table 4 shows the results of the FIML estimation of consumption equations for the three states of migration. Overall, the observed household characteristics, in particular geographical and ward characteristics play a more important role in determining the level of consumption in households without migrants compared with those with a migrant. While a household's human and productive capital has a strong effect on consumption in households without migrants, these factors become less important for households with a migrant when remittances contribute a significant share to the household budget. The loglikelihood test rejects the equality of the coefficients in the consumption regressions for international and domestic migrants. This justifies the assumptions of our theoretical model about the differences in returns on productive and human capital characteristics between international and domestic migrants.

The demographic composition of the household and particularly its dependency ratio have a significant impact on per capita consumption expenditure. Households with larger shares of children aged 0 to 3 years have lower per capita consumption relative to households with either no children or older children. ${ }^{12}$ Household demographics seem to have a stronger effect on consumption in households without migrants or with migrants abroad. Households with larger shares of all groups other than small children and those with better educated female members have higher per capita consumption levels.

The size of landholdings has a positive and significant impact on household consumption regardless of migration state. For households with international migrants, those possessing more than two hectares of land have significantly higher per capita consumption compared with landless households. Looking at the coefficients on the lagged asset index dummies, households from the upper percentiles of the index have

\footnotetext{
${ }^{12}$ Clearly, the effects of household demographic variables will be different if we adjust for scale economies based on household size. This could be relevant in the context of Nepal where the majority of the population lives in large households. However, currently there are no studies that assess the magnitude of economies of scale in Nepal, so we rely on the standard per capita definition for Nepal.
} 
higher per capita expenditure regardless of migration status. Households receiving pensions are better off in all three migration groups.

Our estimations also demonstrate strong regional variation in the level of household consumption for households without migrants: households residing in Katmandu have lower levels of consumption expenditures compared with households from other regions of Nepal. For households with international and domestic migrants, the regional effects are less pronounced. Interestingly, the coefficients on the distance-tomarket variable are insignificant in the estimation of the probability to migrate and only significant in the consumption equation of households without migrants. These results seem to contradict the work of Fafchamp and Shilpi (2003) who find strong correlations between the distance to markets and the level of well-being of Nepali households.

Finally, certain local economic conditions seem to be significantly correlated with levels of household well-being. For example, households in wards with a high proportion of illiteracy are significantly poorer compared with the households in wards where the population is more highly educated. Households either without migrants or with domestic migrants residing in wards with larger shares of self-employment are comparatively worse-off.

\section{Simulations}

Using the estimated parameters of the system of equations (2)-(4), we simulate the effect of migration and remittances on distribution of per capita consumption under various counterfactual regimes of migration. Different levels of domestic and international migration are simulated through the changes in the values of the two instruments. When predicting household expenditures in a counterfactual state with no migration we increase the household size to adjust for the presence of a would-be-migrant, as well as all variables constructed using the household size and shares of various age-gender groups. A detailed discussion of the simulation technique is presented in Appendix 2.

We construct four counterfactual scenarios (Table 5). The first column of Table 5 shows the actual rates of poverty, mean expenditure, and inequality for households 
exhibiting the three different states of migration. ${ }^{13}$ In 2004, 29.9 percent of the Nepali population had per capita consumption expenditure below the poverty line; average per capita consumption was NPR 14,930 per year, and the consumption Gini inequality reached 0.409 .

In the scenario of no migration (the second column in Table 5), households with a migrant have the same returns on their observed characteristics as household without a migrant: the size of the migrant households is increased by one, and remittances are set to zero. Our simulations show that without migration the overall poverty rate in Nepal would have increased from the current 30.0 to 33.6 percent. The share of poverty among households with a domestic migrant would have risen to about 46 percent, and for households with an international migrant poverty would have increased to 35 percent. Overall, inequality would remain virtually unchanged. The consumption expenditure of households without a migrant would remain unaffected, while the average consumption of households with domestic or international migrants would fall.

The second counterfactual scenario models changes in expenditure distribution had the levels of migration and remittances remained unchanged between 1995 and 2004. The values of our two instruments are adjusted such that the proportions of domestic and international migrants are the same in 2004 as they were in $1995 .{ }^{14}$ This scenario results in higher overall poverty (a change from 30.0 to 31.8 percent), and higher poverty rates both among households with domestic migrants (a change from 22.9 to 30.0 percent) and among those with international migrants (32.8 to 37.2 percent). Inequality would slightly decline to Gini 0.407. We can decompose the change in poverty between 1995 and 2004 into 3 components. These components represent the contributions of the changes in the levels of domestic and international migration (non-migrant households sending a

\footnotetext{
${ }^{13}$ The three groups of households in Table 5 are defined based on their observed (actual) household migration outcome. Poverty and inequality statistics are calculated for these household groups under all counterfactual scenarios. For example, the poverty rate for households without migrants remains unchanged between actual and no migration scenarios. The counterfactual poverty rate of 30.5 percent should be interpreted as the poverty rate for households without migrants in the observed state. At the same time, the poverty rate for a group of households with a migrant within Nepal increased from 22.4 to 45.6 percent, which shows the change in poverty status for households from this group under the counterfactual scenario when all migrants stay home.

${ }^{14}$ Theoretically we cannot guarantee the uniqueness of the solution for this nonlinear problem. It appears that in our case there is only one combination of the values of the instruments that solves this problem within the data range.
} 
migrant) to the total poverty change, and the interaction component ${ }^{15}$. This decomposition demonstrates that the increase in international migration between 1995 and 2004 decreased the total poverty by 1.2 percentage points, while the increase in internal migration and the interaction component are responsible for a 0.6 percentage point reduction in poverty in Nepal.

The last two columns of Table 5 present the results of simulations for the hypothetical scenarios of a 10-percentage point growth in the levels of domestic and international migration. These simulations are based on implicit assumptions that this growth is caused by a decrease in the cost of migration and that the average amount of remittances a migrant sends home remains constant. Both scenarios lead to lower overall poverty rates, but the impact of the increase in the rate of domestic migration is larger. Poverty in Nepal would be reduced by 2.4 percentage points if domestic migration were 10 percent higher, and poverty would decline by 0.5 percentage points if international migration were 10 percentage points higher. Both scenarios lead to rising inequality.

The important conclusion that emerges from these simulations is that the elasticity of poverty reduction in Nepal over the past decade is significantly higher for domestic migration than it is for international migration. One explanation for the different effects of domestic and international migration on poverty could be that remittances derived from work in foreign countries are more likely to be invested in productive assets and real estate. This is often attributed to the notion that households receiving international remittances tend to treat such funds as positive transitory income shocks that should be invested. Local remittances are treated as a mixture of transitory and permanent income and are more often used both for investment and for consumption (Alderman 1996). On the other hand, the surge of investment in housing that creates new employment and income opportunities for the local labor force could have a positive impact on local poverty rates (Adams 1998). Our estimation strategy, however, overlooks such effects. It is not clear whether our results would hold if the general equilibrium consequences of changes in migration and remittances were taken into account.

In attempts to disentangle heterogeneity in the impact on poverty of migration and remittances, we present simulated poverty rates for different types of households (Table

\footnotetext{
${ }^{15}$ This decomposition is similar to the poverty decomposition by Ravallion and Huppi (1991).
} 
6). Households with a migrant living in other urban areas of Nepal and in rural western Terai experienced the most significant boost in consumption. Dalit households appear to gain less from sending their members to work in other regions of Nepal or abroad. Relative to the counterfactual scenario of no migration, landless (probably urban) households or those owning large land plots seem to benefit more from migration.

With an estimated increase in poverty of 3.6 percentage points, based on the counterfactual of no migration, the impact of changes in migration for work (together with associated remittances) in Nepal is somewhat lower than the estimated impacts for other countries, even though most of these studies estimate the impact of remittances only. Adams (2005) attributes the effect of remittances to 5 percentage points of poverty reduction in Ghana, 6 percentage points in Bangladesh, and 11 percentage points in Uganda. Completely removing remittances would raise poverty rates by 8 percent points in Lesotho, while the poverty rate in poor areas of China would increase by 1 percentage point in the absence of migration and remittances (Yang, Park, and Wang 2005). On a macro level, Adams and Page estimate the remittance elasticity of poverty to be of around -0.35 . Our model predicts a slightly higher elasticity of -0.51 .

\section{Sensitivity Analysis and Caveats}

Our main empirical specification relies on stringent assumptions that limit our estimation sample and restrict the set of exogenous variables included in the model. In this section we demonstrate how our results would change if these assumptions are relaxed. In particular, we compare the results discussed in the previous section with the results of simulations based on a specification that assumes no correlation between the error terms in the system of equations (2)-(4); the specification that explicitly includes the amount of remittances (both instrumented and uninstrumented); and the specification classifying migrants to India as domestic migrants. The counterfactual poverty rates under various migration scenarios simulated for these empirical specifications are shown in Table $7 .{ }^{16}$

\footnotetext{
${ }^{16}$ The simulated results for inequality and mean consumption expenditures for these specifications are available from the authors on request. The results of FIML estimations of the system of equations (2)-(4) under different specifications are shown in Appendix 3.
} 
The comparison of the main simulation results (Table 5) with simulations under an assumption of a joint independence of the error terms in equations (2)-(4) reveals a systematic relationship between the decision to migrate and the level of household consumption, which is not accounted for by observed household characteristics. The differences in the returns on unobserved characteristics of households with a migrant between the actual and counterfactual scenarios account for more than 60 percent of the total impact that work-related migration and remittances have on aggregate poverty rates. ${ }^{17}$ This indicates significant self-selection on unobservable characteristics that provide higher returns to the households if one of their members migrates.

We simulate the counterfactual distribution of consumption using a specification that explicitly includes remittance amounts in a set of explanatory variables. The results of this estimation are biased because remittances could be endogenous to consumption and are most likely badly measured in our data. Nevertheless, the magnitudes of the estimated effects of migration and remittances are similar for this and our preferred specification. Under the counterfactual of no migration, the poverty rate increases by 4.5 percentage points versus 3.6 percentage points in the preferred specification. For the 1995-96 scenario, the simulated changes in poverty rates based on a specification that includes remittance amounts are equal to 1.4 percentage points, while the preferred specification predicts about a 1.9 percentage point change in poverty. The simulated poverty rates under the specification where the amount of remittances is instrumented with the age of a migrant are very close to the poverty rates obtained from uninstrumented specification.

We next compare our main results with the simulations based on an unrestricted sample. We find that including the previously excluded households in our estimation (that is, those without men of working age and those consisting only of single men) increases the poverty rates in the counterfactual scenarios. Overall, however, the simulated poverty impact of migration for the unrestricted sample is consistent with our main results. Note that the actual poverty rate in that scenario is different from the poverty rates in other scenarios because it is calculated using a larger sample.

\footnotetext{
${ }^{17}$ This result was calculated by comparing the simulated magnitudes of poverty reduction between the FIML and OLS specifications.
} 
Finally, we test the sensitivity of our results for the alternative classification of households by migration destination, whereby migrants to India are categorized as domestic migrants. The concern here is that characteristics of migrants to India could be similar to the characteristics of domestic migrants. Such migrants predominantly come from the rural Terai region of Nepal and are usually involved in agricultural or manual labor for low wages. At the same time, Nepalese working in Arab countries in the Gulf and the Far East are educated, employed in the better paying jobs, and can send more money home. Hence, combining households with migrants from India with those from other countries potentially underestimates the impact of international migration.

The comparison of simulations based on this alternative categorization with those based on the preferred specification results in relatively small differences in the simulated poverty rates. The increase in the poverty rate under the scenario of no migration is smaller (2.8 percentage points) compared with the increase in poverty simulated with the preferred specification (3.6 percentage points). The scenario using 1995/96 levels of migration resulted in a 1.8 percentage point increase in poverty in the specification reclassifying Indian migrants versus a 1.9 percentage point increase using the specification classifying migrants to India as international migrants.

There are several qualifications to and possible caveats on our results. First, our results are obtained using the 2004 cross-sectional data. We have no instruments to control for possible household- or community-level endogeneity. In this sense, our estimations of the impact of work-related migration are valid only to the extent that unobserved family and community characteristics are captured by the variables included in our empirical specification.

Second, our analysis focuses only on the direct impact of migration and remittances on households with a migrant. Migration and remittances improve the welfare of households in the sending communities by stimulating local economic development. Migrants channel remittances into productive investment at home. Even when some households spend most of the remittances on current consumption, the resulting demand for goods and services can be met by other working adults in the community, thus generating strong positive externalities. We argue that our estimates provide lower bounds on the actual impact of migration for work and remittances on 
poverty in Nepal. Taking into account the general equilibrium consequences of workrelated migration would demonstrate an even larger impact on living standards of Nepal.

\section{Conclusions}

This paper attempts to explain the role of migration and remittances in reducing poverty in Nepal between 1995 and 2003. We compared the observed poverty and inequality rates with the rates calculated under counterfactual scenarios. To construct these counterfactuals we estimated the model of household consumption expenditure identifying observed and unobserved differences in the returns on household characteristics based on migration status.

The results of our simulations show that almost 20 percent of the decline in poverty in Nepal between 1995 and 2004 can be attributed to increased work-related migration and the resulting remittances sent back home. In the absence of migration, the poverty rate in Nepal would increase from the currently observed 30.0 percent to 33.6 percent, and the mean per capita expenditure would decline from 15,000 to 14,000 NPR. Almost 58 percent of the aggregate increase in poverty could be accounted for by a higher number of the would-be poor among households with members who migrated internationally. Migration and remittances have only a marginal impact on income inequality in Nepal.

Migration and remittances have a strong impact on the living conditions of households with a migrant. The poverty rate among households with a member who migrates within Nepal would be twice as high as current levels if the migrant had stayed home. The poverty rate for households with a migrant working abroad would also be substantially higher had their members not migrated.

Our findings have important implications for public policy. They emphasize the role of migration for work and remittance inflows in raising the living standards of recipient families and reducing aggregate poverty in Nepal. Hence, strategies for economic growth and poverty reduction in Nepal should incorporate various aspects of the migration dynamics. Our results demonstrate that policies promoting both domestic migration and the export of labor-if such export were accompanied by remittances- 
could also have an important effect on poverty reduction in Nepal. Given that Nepal has such a plentiful supply of labor, migration for work provides employment and earning opportunities for a significant segment of the labor force. Unless the labor market situation changes dramatically, increasing numbers of Nepali men and women will seek job opportunities outside Nepal; migration and remittances could be expected to play even a greater role in the future economic development of the country. 


\section{References}

Adams, R., (1989) "Worker Remittances and Inequality in Rural Egypt," Economic Development and Cultural Change, Vol. 38: 45-71. , (1991) "The Economic Uses and Impact of International Remittances in Rural Egypt," Economic Development and Cultural Change, Vol. 39: 695-722. , (1998) "Remittances, Investment and Rural Asset Accumulation in Pakistan," Economic Development and Cultural Change, Vol. 47 (1): 155-173. , (2005) "Remittances, Household Expenditure, and Investment in Guatemala," Policy Research Working Paper \# 3532, The World Bank, Washington, DC.

Adams, R., and J. Page, (2003) "International Migration, Remittances and Poverty in Developing Countries,” World Bank Policy Research Working Paper \#3179.

Acharya, L., (2001) "Integration of Population in Poverty Alleviation Programmes in Nepal," in B. Kumar, ed., Population and Development in Nepal, Vol. 8: 57-66.

Agesa, R., and S. Kim, (2001) "Rural to Urban Migration as a Household Decision: Evidence from Kenya," Review of Development Economics, Vol. 5 (1) 60-75.

Alderman, H., (1996) "Savings and Economic Shocks in Rural Pakistan," Journal of Development Economics, Vol. 51: 343-365.

Aydemir, A., (2003) "Are Immigrants Positively or Negatively Selected? The Role of Immigrant Selection Criteria and Self-Selection," WUSTL Working Paper Series \#0306002.

Barham, B., and S. Bourcher, (1998) "Migration, Remittances, and Inequality: Estimating the Net Effects of Migration on Income Distribution," Journal of Development Economics, Vol. 55: 307-331.

Bhattacharyya, B., (2005) "The Role of Family Decision in Internal Migration: The Case of India," Journal of Development Economics, Vol. 18: 51-66.

Bhattarai, P., (2005) "Migration of Nepalese Youth for Foreign Employment: Problems and Prospects." Report, Youth Action Nepal, Katmandu.

Borjas, G., (1987) "Self-Selection and the Earnings of Immigrants," American Economic Review, Vol. 77(4): 531-551.

, (1990) "Self-Selection and the Earnings of Immigrants: Reply," American Economic Review, Vol. 80 (1): 305-308.

, (1991) "Immigration and Self-Selection," In Immigration, Trade and the Labor Market, eds. R. B. Freeman and J. Abowd, 29-76. Chicago: U. of Chicago Press.

Carrington, W., E. Detragiache, and T. Vishwanath, (1996) "Migration with Endogenous Moving Costs," American Economic Review, Vol. 86: 909-930.

Central Bureau of Statistics, (2003) "Population Census 2001: National Report," Central Bureau of Statistics, Katmandu.

Chhetry, D., (1999) "Caste/Ethnic Groups as Primary Units of Concern of Poverty," Nepal Population Journal, Vol. 8 (7): 43-48. , (2002), "Population, Development and Poverty in Nepal: An Integrated Approach of Analysis," In B. Kumar Ed., Population and Development in Nepal, Vol. 10: 72-83.

Chiswick, B., (1978) "The Effect of Americanization on the Earnings of Foreign Born Men," Journal of Political Economy, Vol. 88(3): 620-629 
Davidson, R., and J. MacKinnon, (1993) Estimation and Inference in Econometrics, Oxford: Oxford University Press.

Djajic, S., (1986). "Migrants in a Guest-Worker System: A Utility Maximization Approach," Seminar Paper No 386, Institute for International Economic Studies, Stockholm

Docquir, F., and H. Rapoport, (1998) “Are Migrant Minorities Strategically SelfSelected?" Journal of Population Economics, Vol. 11: 579-588.

Du Y., Park, A., and S. Wang, (2005) "Migration and Rural Poverty in China," Journal of Comparative Economics, Vol. 33: 688-709

Do, T., and L. Iyer, (2007) "Poverty, Social Divisions and Conflict in Nepal." Mimeo, The World Bank.

Dustmann, C., and O. Kirchkamp, (2002) "The Optimal Migration Duration and Activity Choice After Re-migration," Journal of Development Economics, Vol. 67: 351372.

Efron, B., (1981) "Nonparametric Estimates of Standard Error: The Jackknife, the Bootstrap and Other Methods," Biometrika, Vol. 68 (3): 589-599.

Fafchamp, M., and F. Shilpi (2003) "The Spatial Division of Labor in Nepal," Journal of Development Studies, Vol. 39 (6): 23-66.

Funkhauser, E. (1992), "Mass emigration, Remittances and Economic Adjustment: The Case of El Salvador in the 1980s," in G. Borjas and R. Freeman Eds., Migration and the Workforce: Economic Consequences for the United States, University of Chicago Press, Chicago, IL.

Gustafsson, B., and N. Makonnen (1993) "Poverty and Remittances in Lesotho," African Economies, Vol. 2 (2): 49-73.

Jha, H., (1999) Status of Informal Sector Workers: The Other Side of Economy in Nepal. Katmandu.

Heckman, J., and G. Sedlacek, (1990) "Self-Selection and the Distribution of Hourly Wages," Journal of Labor Economics, Vol. 43 (1 Part II): S329-263.

Hildebrandt, N., and D. McKenzie, (2004) "The Effects of Migration on Child Health in Mexico", Economia, 6 (1): 257-289.

Hoddinott, J., (1994) "A Model of Migration and Remittances Applied to Western Kenya," Oxford Economic Papers, Vol. 45: 135-151.

Kanbur, R., and H., Rapoport, (2005) "Migration Selectivity and the Evolution of Spatial inequality," Journal of Economic Geography, Vol. 5: 43-57.

Kumar, B., (2003) "Migration, Poverty and Development in Nepal," paper presented for an Expert Group Meeting on Migration and Development, Economic and Social Commission for Asia and the Pacific, Bangkok.

Low, A., (1986) Agricultural Development in Southern Africa: Farm Household Economics and the Food Crisis, London: James Curry.

McKenzie, D., (2005) "Beyond Remittances: The Effect of Migration on Mexican households." Mimeo, World Bank, Washington, DC.

McKenzie, D., and H., Rapoport, (2005) "Migration Networks, Migration Incentives, and Education Inequality in Rural Mexico," Paper presented at the Inter-American Development Bank "Economic Integration, Remittances, and Development" Conference. 
McKenzie, D., J. Gibson, and S. Stillman, (2006) "How Important is Selection? Experimental vs. Non-Experimental Measures of the Income Gains from Migration," IZA Discussion Paper Series \#2087.

Mesnard, A., (2004) "Temporary Migration and Capital Market Imperfections," Oxford Economic Papers, Vol. 56: 242-262.

Mroz, T. (1999) "Discrete Factor Approximations in Simultaneous Equation Models: Estimating the Impact of a Dummy Endogenous Variable on a Continuous Outcome." Journal of Econometrics, Vol. 92 (2): 233-274.

Munshi, K., (2003) "Networks in the Modern Economy: Mexican Migrants in the U. S. Labor Market," Quarterly Journal of Economics, 118 (2): 549-599.

Nandini, A. (1999) Engendered Mobilization-The Key to Livelihood Security: IFAD's Experience in South Asia. Rome: IFAD.

Nepal Ministry of Health (2002) Nepal Demographic and Health Survey 2001: Final Report, Family Health Division, Department of Health Services, Ministry of Health; New ERA; ORC Macro; Katmandu.

Ravallion, M., and M. Huppi, (1991) 'Measuring changes in Poverty: a Methodological Case Study of Indonesia during an Adjustment Period', World Bank Economic Review, Vol. 5:57-82.

Rapoport H., and F. Docquier (2004) “The Economics of Migrants' Remittances," in G. Varet, K. Ythier, and M. Ythier, eds. Handbook of the Economics of Reciprocity, Giving and Altruism, North Holland.

Sheddon, D., (2005) "Nepal's Dependence on Exporting Labor," Migration Policy Institute, Washington, DC. http://www.migrationinformation.org/Profiles/display.cfm?id=277.

Sheddon, D., J. Adhikari, and G. Gurung, (2000) "Foreign Labor Migration and the Remittance Economy of Nepal," A Report to DFID, Katmandu.

Stark, O., (1978), "Economic-Demographic Interaction in the Course of Agricultural Development: The Case of Rural-to-Urban Migration," Research Report \#2/78, David Horowitz Institute for Research of Developing Countries, Tel Aviv. , (1991), The Migration of Labor, Blackwell, Cambridge, Massachusetts.

Stark, O.and D. Levhari. 1982. "On Migration and Risk in LDCs." Economic Development and Cultural Change Vol. 31:191-196.

Stark, O., and R. Lucas (1988) "Migration, Remittances, and the Family," Economic Development and Cultural Change, 36 (3): 465-481.

Taylor, E., and T. Wyatt (1996) "The Shadow Value of Migrant Remittances, Income and Inequality in a Household-farm Economy", Journal of Development Studies, Vol. 32 (6): 899-912.

Taylor, E., and S. Rozelee (2003) "Migration and Incomes in Source Communities: A New Economics of Migration Perspective from China," Economic Development and Cultural Change, Vol. 52: 75-101.

Taylor, E., and J. Mora (2006) "Does Migration Reshape Expenditures in Rural Household? Evidence from Mexico," World Bank Policy Research Working Paper \#3842, The World Bank.

Thapliyal, S. (1999) "Movement of Population between India and Nepal: Emerging Challenges," Strategic analysis, Vol. 23 (5), http://www.ciaonet.org/olj/sa/sa_aug99.html. 
Thieme, S., (2003) "Savings and Credit Associations and Remittances: The case of Far West Nepalese Labor Migrants in Delhi, India," Working Paper \#39, Employment Sector, International Labor Office, Geneva.

The World Bank, (2004) "Nepal Development Policy Review: Restarting Growth and Poverty Reduction," Report 29382-NP, Poverty Reduction and Economic Management, South Asia Region, The World Bank, Washington, DC. , (2005) "Consumption Poverty in Nepal in 1995-96 and 2003-04:

Measurement Issues and Trends," mimeo, South Asia Poverty Reduction and Economic Management Unit, The World Bank, Washington, DC. , (2006) "Nepal, Resilience Amidst Conflict: An Assessment of Poverty in Nepal, 1995-96 and 2003-04,” Report \#34843-NP, Poverty Reduction and Economic Management Sector Unit, South Asia Region, The World Bank, Washington, DC.

Woodruff, C., and R. Zenteno, (2001) "Remittances and Microenterprises in Mexico," mimeo, University of California in San Diego, San Diego, CA.

Yamanaka, K., (2003) "Nepalese Labour Migration to Japan: From Global Warriors to Global Workers," Ethnic and Racial Studies, Vol. 23 (1): 62-93.

Yang, D., and H. Choi, (2005) "Are Remittances Insurance? Evidence from Rainfall Shocks in the Philippines," Ford School of Public Policy Working Paper Series No. 05-004. 
Table 1: Percent of households receiving remittances by regions of Nepal and total

\begin{tabular}{|c|c|c|c|c|c|c|}
\hline & \multicolumn{2}{|c|}{$\begin{array}{l}\text { Receive remittances } \\
\text { from Nepal }\end{array}$} & \multicolumn{2}{|c|}{$\begin{array}{l}\text { Receive remittances } \\
\text { from abroad }\end{array}$} & \multicolumn{2}{|c|}{$\begin{array}{r}\text { Receive any } \\
\text { remittances }\end{array}$} \\
\hline & $1995 / 96$ & $2003 / 04$ & 1995/96 & $2003 / 04$ & $1995 / 96$ & $2003 / 04$ \\
\hline \multicolumn{7}{|l|}{ Regions } \\
\hline Kathmandu & 14.3 & 7.8 & 3.6 & 5.7 & 17.9 & 13.5 \\
\hline Other urban areas & 13.1 & 17.1 & 6.0 & 14.3 & 19.2 & 31.3 \\
\hline Rural West mount/hills & 10.6 & 11.1 & 19.6 & 29.4 & 30.2 & 40.4 \\
\hline Rural Eastern mount/hills & 11.1 & 16.9 & 2.0 & 9.3 & 13.1 & 26.2 \\
\hline Rural western Terai & 12.0 & 12.6 & 10.6 & 19.2 & 22.6 & 31.8 \\
\hline Rural eastern Terai & 14.7 & 14.6 & 11.0 & 18.1 & 25.7 & 32.7 \\
\hline \multicolumn{7}{|l|}{ Land holdings a year ago. } \\
\hline No farm plot & 11.3 & 14.8 & 10.2 & 13.2 & 21.4 & 28.0 \\
\hline Farm plot $<0.5$ ha & 13.1 & 14.3 & 11.7 & 18.5 & 24.7 & 32.8 \\
\hline Farm plot $0.5-1$ ha & 11.7 & 11.7 & 10.7 & 20.0 & 22.5 & 31.8 \\
\hline Farm plot: $1-2$ ha & 12.8 & 13.7 & 11.4 & 17.5 & 24.2 & 31.2 \\
\hline Farm plot $>2$ ha & 11.9 & 17.3 & 6.2 & 18.3 & 18.1 & 35.6 \\
\hline \multicolumn{7}{|l|}{ Caste } \\
\hline Brahman $\backslash$ Chhetri & 13.4 & 15.8 & 11.1 & 19.9 & 24.5 & 35.7 \\
\hline Dalit & 12.0 & 9.8 & 15.1 & 24.7 & 27.0 & 34.5 \\
\hline Newar & 13.2 & 14.3 & 3.6 & 7.8 & 16.8 & 22.1 \\
\hline Terai-Hill Janajatis & 9.8 & 14.6 & 9.4 & 15.4 & 19.2 & 30.0 \\
\hline Muslim $\backslash$ Other Minorities & 13.1 & 12.1 & 11.4 & 18.3 & 24.4 & 30.3 \\
\hline Total & 12.3 & 13.9 & 10.6 & 17.7 & 23.0 & 31.6 \\
\hline
\end{tabular}


Table 2: Summary statistics of main explanatory variables for migrant and non-migrant households, 2004 cross-section

\begin{tabular}{|c|c|c|c|c|c|c|}
\hline & \multicolumn{2}{|c|}{$\begin{array}{c}\text { Non-Migrant } \\
\text { households }\end{array}$} & \multicolumn{2}{|c|}{$\begin{array}{c}\text { Domestic migrant } \\
\text { households }\end{array}$} & \multicolumn{2}{|c|}{$\begin{array}{c}\text { International migrant } \\
\text { household }\end{array}$} \\
\hline & Mean & Std. Err. & Mean & Std. Err. & Mean & Std. Err. \\
\hline Household per capita expenditure $\times 10^{5}$ & 1.640 & 0.036 & 1.755 & 0.069 & 1.606 & 0.067 \\
\hline \multicolumn{7}{|l|}{ Household Demographic (before migration) } \\
\hline Household size & 5.683 & 0.050 & 5.803 & 0.114 & 6.491 & 0.107 \\
\hline Share of children age $0-3$ & 0.092 & 0.002 & 0.066 & 0.004 & 0.091 & 0.004 \\
\hline Share of children age $4-7$ & 0.101 & 0.003 & 0.062 & 0.004 & 0.099 & 0.005 \\
\hline Share of children age $8-15$ & 0.192 & 0.004 & 0.149 & 0.007 & 0.163 & 0.006 \\
\hline Share of adult men $16-64$ & 0.031 & 0.002 & 0.080 & 0.007 & 0.040 & 0.004 \\
\hline Share of women $16-64$ & 0.286 & 0.003 & 0.279 & 0.006 & 0.279 & 0.004 \\
\hline Share of elderly age $65+$ & 0.298 & 0.003 & 0.364 & 0.007 & 0.328 & 0.006 \\
\hline Number of married couples & 1.314 & 0.014 & 1.205 & 0.034 & 1.491 & 0.034 \\
\hline Maximum education of women & 1.011 & 0.027 & 1.035 & 0.057 & 1.052 & 0.052 \\
\hline \multicolumn{7}{|l|}{ Ethnicity } \\
\hline Brahman/Chhetri & 0.290 & 0.009 & 0.356 & 0.021 & 0.349 & 0.019 \\
\hline Dalit & 0.073 & 0.005 & 0.058 & 0.010 & 0.113 & 0.013 \\
\hline Newar & 0.086 & 0.006 & 0.076 & 0.012 & 0.032 & 0.007 \\
\hline Terai-Hill Janajatis & 0.273 & 0.009 & 0.283 & 0.020 & 0.233 & 0.017 \\
\hline Muslim $\backslash$ Other Minorities & 0.279 & 0.009 & 0.227 & 0.018 & 0.273 & 0.018 \\
\hline \multicolumn{7}{|l|}{ Land holdings a year ago } \\
\hline Landless households & 0.246 & 0.009 & 0.232 & 0.018 & 0.174 & 0.015 \\
\hline Farm plot $<0.5$ hectares & 0.366 & 0.010 & 0.374 & 0.021 & 0.402 & 0.019 \\
\hline Farm plot: $0.5-1$ hectares & 0.211 & 0.008 & 0.190 & 0.017 & 0.224 & 0.017 \\
\hline Farm plot $1-2$ hectares & 0.121 & 0.007 & 0.131 & 0.015 & 0.141 & 0.014 \\
\hline Farm plot $>2$ hectares & 0.056 & 0.005 & 0.073 & 0.011 & 0.059 & 0.009 \\
\hline \multicolumn{7}{|l|}{ Lagged durable asset index } \\
\hline No assets & 0.397 & 0.010 & 0.409 & 0.022 & 0.431 & 0.020 \\
\hline \multirow{2}{*}{$\begin{aligned} \text { Asset poor } & \left(1-33^{\text {th }} \text { percentile }\right) \\
& \left(33^{\text {th }}-66^{\text {th }} \text { percentile }\right)\end{aligned}$} & 0.222 & 0.008 & 0.246 & 0.019 & 0.212 & 0.016 \\
\hline & 0.209 & 0.008 & 0.216 & 0.018 & 0.212 & 0.016 \\
\hline Asset rich $\left(66^{\text {th }}-100^{\text {th }}\right.$ percentile $)$ & 0.172 & 0.008 & 0.129 & 0.015 & 0.144 & 0.014 \\
\hline \multicolumn{7}{|l|}{ Geography dummies } \\
\hline Katmandu & 0.075 & 0.005 & 0.034 & 0.008 & 0.018 & 0.005 \\
\hline Other urban areas & 0.107 & 0.006 & 0.128 & 0.015 & 0.084 & 0.011 \\
\hline Rural Western mountains/hills & 0.172 & 0.008 & 0.170 & 0.016 & 0.359 & 0.019 \\
\hline Rural Eastern mountains/hills & 0.226 & 0.008 & 0.260 & 0.019 & 0.111 & 0.012 \\
\hline Rural Western Terai & 0.142 & 0.007 & 0.127 & 0.015 & 0.148 & 0.014 \\
\hline Rural Eastern Terai & 0.278 & 0.009 & 0.281 & 0.020 & 0.280 & 0.018 \\
\hline Log Distance to market center & 2.095 & 0.028 & 2.024 & 0.057 & 2.220 & 0.048 \\
\hline Per capita pension transfers & 0.389 & 0.050 & 0.345 & 0.094 & 0.655 & 0.116 \\
\hline \multicolumn{7}{|l|}{ Ward level variables } \\
\hline$\%$ illiterate, among age $15+$ & 0.560 & 0.004 & 0.542 & 0.009 & 0.569 & 0.009 \\
\hline$\%$ literate or $1-4$ years of education & 0.180 & 0.002 & 0.191 & 0.005 & 0.187 & 0.005 \\
\hline$\%$ completed $5-7$ years of education & 0.108 & 0.001 & 0.114 & 0.003 & 0.114 & 0.003 \\
\hline$\%$ employed in wage job & 0.145 & 0.003 & 0.127 & 0.005 & 0.141 & 0.005 \\
\hline$\%$ self employed & 0.462 & 0.005 & 0.492 & 0.010 & 0.482 & 0.009 \\
\hline Average log expenditure & 8.896 & 0.007 & 8.897 & 0.014 & 8.826 & 0.013 \\
\hline Gini coefficient & 0.312 & 0.001 & 0.312 & 0.003 & 0.304 & 0.003 \\
\hline Casualties from conflict, district level & 0.565 & 0.014 & 0.522 & 0.023 & 0.611 & 0.027 \\
\hline Number of Observations & \multicolumn{2}{|c|}{2,464} & \multicolumn{2}{|c|}{523} & \multicolumn{2}{|c|}{633} \\
\hline
\end{tabular}


Table 3: FIML estimation of the migration choice part of the system (1-3)

\begin{tabular}{|c|c|c|c|c|}
\hline \multirow[t]{2}{*}{ Base category: No Migration } & \multicolumn{2}{|c|}{ Domestic Migration } & \multicolumn{2}{|c|}{ International Migration } \\
\hline & Coefficient & Std. Error & Coefficient & Std. Error \\
\hline Share of domestic migrants in district, 1995 & $1.059^{* * *}$ & 0.285 & -0.418 & 0.333 \\
\hline Share of international migrants in a ward, 2001 & 0.165 & 0.228 & $1.266^{* * *}$ & 0.192 \\
\hline \multicolumn{5}{|l|}{ Household Demographics (before migration) } \\
\hline Household size & $0.158^{* * *}$ & 0.017 & $0.127^{* * *}$ & 0.016 \\
\hline \multicolumn{5}{|l|}{ Share of children 0-3: Omitted variable } \\
\hline Share of children 4-7 & -0.192 & 0.371 & 0.162 & 0.330 \\
\hline Share of children $8-15$ & -0.058 & 0.272 & $-0.416^{*}$ & 0.248 \\
\hline Share of men $16-64$ & $1.156^{* * *}$ & 0.331 & 0.236 & 0.329 \\
\hline Share of women 16-64 & $1.996^{* * *}$ & 0.283 & $1.312^{* * *}$ & 0.265 \\
\hline Share of elderly & $2.952^{* * *}$ & 0.345 & $0.932^{* * *}$ & 0.357 \\
\hline Number of married couples & $-0.379^{* * *}$ & 0.051 & $-0.089^{*}$ & 0.049 \\
\hline Maximum education of women in the household & 0.005 & 0.026 & 0.024 & 0.025 \\
\hline \multicolumn{5}{|l|}{ Ethnicity: Reference Category: Brahman $\backslash$ Chhetri } \\
\hline Dalit & $-0.268^{* *}$ & 0.119 & 0.021 & 0.101 \\
\hline Newar & $-0.244^{* *}$ & 0.106 & $-0.452^{* * *}$ & 0.124 \\
\hline Terai-Hill Janajatis & $-0.161^{* *}$ & 0.074 & -0.107 & 0.072 \\
\hline Muslim $\backslash$ Other Minorities & $-0.281^{* * *}$ & 0.085 & -0.103 & 0.080 \\
\hline \multicolumn{5}{|c|}{ Land holdings a year ago: Reference Category: No farm plot } \\
\hline Farm plot $<0.5$ ha & -0.061 & 0.078 & 0.036 & 0.077 \\
\hline Farm plot $0.5-1$ ha & $-0.247^{* * *}$ & 0.096 & -0.100 & 0.091 \\
\hline Farm plot: $1-2$ ha & -0.144 & 0.107 & -0.029 & 0.102 \\
\hline Farm plot $>2$ ha & -0.156 & 0.132 & -0.192 & 0.132 \\
\hline \multicolumn{5}{|c|}{ Lagged durable asset index: Reference Category: No durables } \\
\hline Asset poor $\left(1-33^{\text {th }}\right.$ percentile $)$ & 0.057 & 0.073 & $-0.135^{*}$ & 0.071 \\
\hline$\left(33^{\text {th }}-66^{\text {th }}\right.$ percentile $)$ & -0.056 & 0.077 & $-0.141^{*}$ & 0.075 \\
\hline Asset rich $\left(66^{\text {th }}-100^{\text {th }}\right.$ percentile $)$ & $-0.324^{* * *}$ & 0.096 & -0.139 & 0.091 \\
\hline Total pensions per capita & -0.015 & 0.012 & $0.016^{*}$ & 0.008 \\
\hline \multicolumn{5}{|l|}{ Geography dummies: Reference Category: Katmandu } \\
\hline Other urban areas & $0.702^{* * *}$ & 0.145 & $0.565^{* * *}$ & 0.155 \\
\hline Rural west mount/hills & $0.563^{* * *}$ & 0.190 & $1.042^{* * *}$ & 0.193 \\
\hline Rural eastern mount/hills & $0.574^{* * *}$ & 0.173 & $0.479^{* * *}$ & 0.184 \\
\hline Rural western Terai & $0.655^{* * *}$ & 0.184 & $0.739^{* * *}$ & 0.189 \\
\hline Rural eastern Terai & $0.807^{* * *}$ & 0.167 & $0.838^{* * *}$ & 0.175 \\
\hline Log of distance to market center & -0.041 & 0.027 & -0.015 & 0.025 \\
\hline \multicolumn{5}{|l|}{ Ward level variables } \\
\hline$\%$ illiterate, among age $15+$ & $-0.544^{*}$ & 0.312 & 0.029 & 0.307 \\
\hline$\%$ literate or $1-4$ years of education & -0.556 & 0.463 & 0.416 & 0.448 \\
\hline$\%$ completed 5-7 years of education & -0.197 & 0.511 & 0.405 & 0.495 \\
\hline$\%$ employed in wage job & -0.053 & 0.358 & 0.481 & 0.315 \\
\hline$\%$ self employed & $0.549^{* *}$ & 0.216 & -0.031 & 0.198 \\
\hline Log of average household expenditure, 1995 & 0.063 & 0.108 & 0.131 & 0.105 \\
\hline Gini coefficient, 1995 & 0.022 & 0.464 & $-0.916^{* *}$ & 0.435 \\
\hline Casualties from conflict, district level & -0.024 & 0.053 & -0.036 & 0.048 \\
\hline Constant & $-3.169^{* * *}$ & 1.048 & $-3.556^{* * *}$ & 1.023 \\
\hline Number of observations & \multicolumn{4}{|c|}{3620} \\
\hline Log-Likelihood & \multicolumn{4}{|c|}{-4266.64} \\
\hline
\end{tabular}

Note: ${ }^{*}$ is significant at $10 \%$ level; ${ }^{* *}$ at $5 \%$ level; ${ }^{* * *}$ at $1 \%$ level; ${ }^{*}$ indicates joint significance of coefficients at $10 \%$ level. 
Table 4: FIML estimation of expenditure equations of the system (1-3)

\begin{tabular}{|c|c|c|c|c|c|c|}
\hline & \multicolumn{2}{|c|}{ Domestic Migration } & \multicolumn{2}{|c|}{ International Migration } & \multicolumn{2}{|c|}{ No Migration } \\
\hline & Coeff. & Std.Err. & Coeff. & Std.Err. & Coeff. & Std.Err \\
\hline \multicolumn{7}{|c|}{ Household Demographics (before migration) } \\
\hline Household size & $-0.120^{* * *}$ & 0.014 & $-0.101^{* * *}$ & 0.017 & $-0.074^{* * *}$ & 0.006 \\
\hline \multicolumn{7}{|c|}{ Share of children 0-3: Omitted variable } \\
\hline Share of children $4-7$ & 0.319 & 0.217 & 0.137 & 0.162 & $0.175^{*}$ & 0.093 \\
\hline Share of children 8-15 & $0.278^{*}$ & 0.159 & $0.613^{* * *}$ & 0.125 & $0.359^{* * *}$ & 0.069 \\
\hline Share of men 16-64 & 0.161 & 0.188 & $0.386^{* *}$ & 0.190 & $0.228^{* *}$ & 0.094 \\
\hline Share of women 16-64 & 0.272 & 0.180 & $0.493^{* *}$ & 0.219 & $0.748^{* * *}$ & 0.091 \\
\hline Share of elderly & -0.180 & 0.201 & 0.222 & 0.245 & $0.260^{* *}$ & 0.131 \\
\hline Number of married couples & $0.150^{* * *}$ & 0.040 & $0.081^{* *}$ & 0.036 & $0.067^{* * *}$ & 0.018 \\
\hline Maximum education of women & $0.034^{* *}$ & 0.017 & $0.081^{* * *}$ & 0.015 & $0.086^{* * *}$ & 0.007 \\
\hline \multicolumn{7}{|c|}{ Ethnicity: Reference Category: Brahman $\backslash$ Chhetri } \\
\hline Dalit & $-0.151^{*}$ & 0.088 & $-0.233^{* * *}$ & 0.058 & $-0.170^{* * *}$ & 0.033 \\
\hline Newar & 0.049 & 0.070 & 0.074 & 0.100 & -0.002 & 0.031 \\
\hline Terai-Hill Janajatis & -0.075 & 0.053 & $-0.125^{* * *}$ & 0.047 & $-0.217^{* * *}$ & 0.022 \\
\hline Muslim $\backslash$ Other Minorities & 0.024 & 0.059 & $-0.151^{* * *}$ & 0.052 & $-0.132^{* * *}$ & 0.025 \\
\hline \multicolumn{7}{|c|}{ Land holdings a year ago: Reference Category: No farm plot } \\
\hline Farm plot $<0.5$ ha & -0.003 & 0.053 & 0.007 & 0.051 & $0.062^{* * *}$ & 0.022 \\
\hline Farm plot $0.5-1$ ha & $0.215^{* * *}$ & 0.066 & 0.055 & 0.062 & $0.143^{* * *}$ & 0.028 \\
\hline Farm plot: $1-2$ ha & $0.181^{* * *}$ & 0.070 & $0.120^{*}$ & 0.064 & $0.206^{* * *}$ & 0.032 \\
\hline Farm plot $>2$ ha & $0.266^{* * *}$ & 0.088 & $0.320^{* * *}$ & 0.081 & $0.330^{* * *}$ & 0.040 \\
\hline \multicolumn{7}{|c|}{ Lagged durable asset index: Reference Category: No durables } \\
\hline Asset poor $\left(1-33^{\text {th }}\right.$ percentile $)$ & 0.053 & 0.051 & 0.070 & 0.047 & 0.004 & 0.022 \\
\hline$\left(33^{\text {th }}-66^{\text {th }}\right.$ percentile $)$ & $0.175^{* * *}$ & 0.052 & $0.185^{* * *}$ & 0.047 & $0.167^{* * *}$ & 0.023 \\
\hline Asset rich $\left(66^{\text {th }}-100^{\text {th }}\right.$ percentile $)$ & $0.558^{* * *}$ & 0.066 & $0.518^{* * *}$ & 0.064 & $0.491^{* * *}$ & 0.028 \\
\hline Total pensions per capita & $0.019^{* *}$ & 0.009 & $0.022^{* * *}$ & 0.005 & $0.015^{* * *}$ & 0.003 \\
\hline \multicolumn{7}{|c|}{ Geography dummies: Reference Category: Katmandu } \\
\hline Other urban areas & -0.103 & 0.106 & -0.044 & 0.136 & $0.195^{* * *}$ & 0.041 \\
\hline Rural west mount/hills & -0.063 & 0.136 & -0.284 & 0.176 & $0.240^{* * *}$ & 0.059 \\
\hline Rural eastern mount/hills & -0.101 & 0.123 & -0.225 & 0.139 & $0.114^{* *}$ & 0.048 \\
\hline Rural western Terai & 0.039 & 0.131 & -0.199 & 0.153 & $0.218^{* * *}$ & 0.053 \\
\hline Rural eastern Terai & -0.071 & 0.124 & 0.002 & 0.149 & $0.299^{* * *}$ & 0.049 \\
\hline Log of distance to market center & -0.024 & 0.019 & -0.017 & 0.016 & $-0.023^{* * *}$ & 0.008 \\
\hline \multicolumn{7}{|l|}{ Ward level variables } \\
\hline$\%$ illiterate, among age $15+$ & -0.250 & 0.208 & -0.239 & 0.195 & $-0.369^{* * *}$ & 0.089 \\
\hline$\%$ literate or $1-4$ years of education & 0.029 & 0.301 & -0.354 & 0.289 & -0.115 & 0.136 \\
\hline$\%$ completed 5-7 years of education & 0.516 & 0.337 & -0.329 & 0.316 & $-0.603^{* * *}$ & 0.148 \\
\hline$\%$ employed in wage job & 0.099 & 0.274 & -0.080 & 0.185 & -0.117 & 0.098 \\
\hline$\%$ self employed & $-0.333^{* *}$ & 0.149 & -0.144 & 0.125 & $-0.223^{* * *}$ & 0.064 \\
\hline Log of average hh expenditure, 1995 & $0.149^{* *}$ & 0.073 & $0.261^{* * *}$ & 0.062 & $0.320^{* * *}$ & 0.032 \\
\hline Gini coefficient, 1995 & 0.339 & 0.301 & 0.213 & 0.258 & 0.052 & 0.144 \\
\hline Casualties from conflict, district level & $0.081^{*}$ & 0.042 & 0.027 & 0.030 & -0.010 & 0.014 \\
\hline Constant & -0.506 & 0.751 & $-1.757^{* *}$ & 0.759 & $-2.782^{* * *}$ & 0.314 \\
\hline Number of observations & \multicolumn{6}{|c|}{3,620} \\
\hline Log-Likelihood & \multicolumn{6}{|c|}{$-4,263.98$} \\
\hline
\end{tabular}

Note: ${ }^{*}$ is significant at $10 \%$ level; ${ }^{* *}$ at $5 \%$ level; ${ }^{* * *}$ at $1 \%$ level; ${ }^{*}$ indicates joint significance of coefficients at $10 \%$ level. 
Table 5: Simulated levels of expenditure, poverty and inequality rates for different migration scenarios.

\begin{tabular}{|c|c|c|c|c|c|}
\hline Migration scenarios & Actual & $\begin{array}{c}\text { No } \\
\text { migration }\end{array}$ & $\begin{array}{c}\text { Level of } \\
\text { migration } \\
\text { as of } 1995 / 96\end{array}$ & $\begin{array}{l}+10 \% \text { point } \\
\text { increase } \\
\text { in domestic } \\
\text { migration }\end{array}$ & $\begin{array}{c}+10 \% \text { point } \\
\text { increase } \\
\text { in } \\
\text { international } \\
\text { migration }\end{array}$ \\
\hline Household types & \multicolumn{5}{|c|}{ Poverty rate (\%) } \\
\hline All Households & 30.0 & $33.6^{*}$ & $31.8^{*}$ & $27.6^{*}$ & 29.5 \\
\hline $\begin{array}{l}\text { Households with no } \\
\text { migrants }\end{array}$ & 30.6 & 30.6 & 30.6 & $27.6^{*}$ & 29.3 \\
\hline $\begin{array}{l}\text { Households with } \\
\text { migrants within Nepal }\end{array}$ & 22.9 & $46.3^{*}$ & $30.0^{*}$ & 22.9 & 25.5 \\
\hline $\begin{array}{l}\text { Households with } \\
\text { migrants abroad }\end{array}$ & 32.8 & 34.9 & 37.2 & 30.7 & 32.8 \\
\hline \multicolumn{6}{|c|}{ Average expenditure, $N R P 10,000$ 's } \\
\hline All Households & 1.493 & $1.405^{*}$ & $1.446^{*}$ & $1.561^{*}$ & 1.515 \\
\hline $\begin{array}{l}\text { Households with no } \\
\text { migrants }\end{array}$ & 1.493 & 1.493 & 1.493 & $1.585^{*}$ & 1.536 \\
\hline $\begin{array}{l}\text { Households with } \\
\text { migrants within Nepal }\end{array}$ & 1.576 & $1.087^{*}$ & $1.401^{*}$ & 1.576 & 1.527 \\
\hline $\begin{array}{l}\text { Households with } \\
\text { migrants abroad }\end{array}$ & 1.441 & 1.341 & 1.328 & 1.478 & 1.441 \\
\hline & \multicolumn{5}{|c|}{ Inequality rate (Gini) } \\
\hline All Households & 0.409 & 0.405 & 0.407 & 0.412 & 0.412 \\
\hline
\end{tabular}

Note: Shaded cells indicate that the poverty rates and average expenditure of these households are not affected by the simulated policy changes.

* indicates that the difference between the actual and simulated values is statistically significant at least 5 percent level. 
Table 6: Simulated changes in predicted per capita consumption for different counterfactual scenarios by household characteristics (NPR 10,000)

\begin{tabular}{|c|c|c|c|c|c|}
\hline \multirow[b]{2}{*}{ Conditional on: } & \multicolumn{5}{|c|}{ Expected consumption } \\
\hline & Actual & $\begin{array}{c}\text { No } \\
\text { migration }\end{array}$ & $\begin{array}{c}\text { Level of } \\
\text { migration } \\
\text { as of } \\
1995 / 96 \\
\end{array}$ & $\begin{array}{c}+10 \% \text { point } \\
\text { increase in } \\
\text { domestic } \\
\text { migration }\end{array}$ & $\begin{array}{c}+10 \% \text { point } \\
\text { increase in } \\
\text { international } \\
\text { migration }\end{array}$ \\
\hline \multicolumn{6}{|l|}{ Ethnicity } \\
\hline Brahman/Chhetri & 1.850 & 1.752 & 1.796 & 1.934 & 1.872 \\
\hline Dalit & 1.052 & 1.033 & 1.030 & 1.088 & 1.059 \\
\hline Newar & 2.670 & 2.557 & 2.611 & 2.770 & 2.696 \\
\hline Terai-Hill Janajatis & 1.174 & 1.068 & 1.123 & 1.232 & 1.205 \\
\hline Muslim $\backslash$ Other Minorities & 1.254 & 1.182 & 1.213 & 1.316 & 1.269 \\
\hline \multicolumn{6}{|l|}{ Land holdings a year ago } \\
\hline Landless households & 1.862 & 1.737 & 1.804 & 1.937 & 1.891 \\
\hline Farm plot $<1$ ha & 1.296 & 1.224 & 1.255 & 1.362 & 1.314 \\
\hline Farm plot: $1-2$ ha & 1.549 & 1.465 & 1.501 & 1.619 & 1.571 \\
\hline Farm plot $>2$ ha & 1.876 & 1.762 & 1.810 & 1.943 & 1.912 \\
\hline \multicolumn{6}{|l|}{ Lagged durable asset index } \\
\hline No Assets & 1.021 & 0.963 & 0.989 & 1.068 & 1.035 \\
\hline Asset poor $\left(1-33^{\text {th }}\right.$ percentile $)$ & 1.076 & 0.988 & 1.035 & 1.142 & 1.093 \\
\hline$\left(33^{\text {th }}-66^{\text {th }}\right.$ percentile $)$ & 1.471 & 1.380 & 1.422 & 1.550 & 1.491 \\
\hline Asset rich $\left(66^{\text {th }}-100^{\text {th }}\right)$ & 3.104 & 2.949 & 3.015 & 3.210 & 3.157 \\
\hline \multicolumn{6}{|l|}{ Geography dummies } \\
\hline Katmandu & 3.495 & 3.334 & 3.418 & 3.591 & 3.541 \\
\hline Other urban areas & 2.476 & 2.291 & 2.391 & 2.572 & 2.527 \\
\hline Rural western mount/hills & 1.187 & 1.154 & 1.157 & 1.241 & 1.203 \\
\hline Rural eastern mount/hills & 1.137 & 1.064 & 1.105 & 1.196 & 1.150 \\
\hline Rural western Terai & 1.269 & 1.177 & 1.223 & 1.368 & 1.280 \\
\hline Rural eastern Terai & 1.388 & 1.300 & 1.336 & 1.443 & 1.414 \\
\hline Total & 1.493 & 1.405 & 1.446 & 1.561 & 1.515 \\
\hline
\end{tabular}


Table 7: Simulated changes in poverty rates in four migration scenarios estimated under the different assumption.

\begin{tabular}{|c|c|c|c|c|c|}
\hline Migration scenarios & Actual & $\begin{array}{c}\text { No } \\
\text { migration }\end{array}$ & $\begin{array}{c}\text { Level of } \\
\text { migration } \\
\text { as in } 1995- \\
96\end{array}$ & $\begin{array}{l}+10 \% \text { point } \\
\text { increase in } \\
\text { domestic } \\
\text { migration }\end{array}$ & $\begin{array}{c}+10 \% \text { point } \\
\text { increase in } \\
\text { international } \\
\text { migration }\end{array}$ \\
\hline & \multicolumn{5}{|c|}{ Poverty rate (\%) } \\
\hline $\begin{array}{l}\text { Preferred specification } \\
\text { (from Table 5) }\end{array}$ & 30.0 & 33.6 & 31.9 & 27.3 & 29.5 \\
\hline \multicolumn{6}{|l|}{ Alternative specifications } \\
\hline $\begin{array}{l}\text { Assuming independence of } \\
\text { error terms in }(1-3) \\
\text { [Tables A3.1 and A4.1] }\end{array}$ & 30.1 & 31.1 & 30.8 & 29.9 & 30.1 \\
\hline $\begin{array}{l}\text { Including amounts of } \\
\text { remittances (not instrumented) } \\
\text { [Tables A3.2 and A4.2] }\end{array}$ & 29.0 & 33.5 & 30.4 & 26.9 & 29.4 \\
\hline $\begin{array}{l}\text { Including amounts of } \\
\text { remittances instrumented by } \\
\text { age of a sender } \\
\text { [Tables A3.3 and A4.3] }\end{array}$ & 29.5 & 33.6 & 30.5 & 27.2 & 29.0 \\
\hline $\begin{array}{l}\text { Unrestricted Sample } \\
(3,874 \text { households }) \\
\text { [Tables A3.4 and A4.4] }\end{array}$ & 30.0 & 34.3 & 32.0 & 28.0 & 29.2 \\
\hline $\begin{array}{l}\text { Treating India as domestic } \\
\text { destination } \\
\text { [Table A3.5 and A4.5] }\end{array}$ & 29.9 & 32.7 & 31.7 & 28.4 & 27.2 \\
\hline $\begin{array}{l}\text { Assuming equal returns in } 3 \\
\text { states of migration in } \\
\text { consumption equations } \\
\text { [Table A3.6 and A4.6] }\end{array}$ & 30.1 & 35.8 & 31.6 & 28.3 & 30.8 \\
\hline
\end{tabular}

Note: that the "actual" poverty rates are simulations based on the model with the initial values of instrumental variables. So, the alternative specifications produce different poverty rates for the simulated "actual" scenario. 

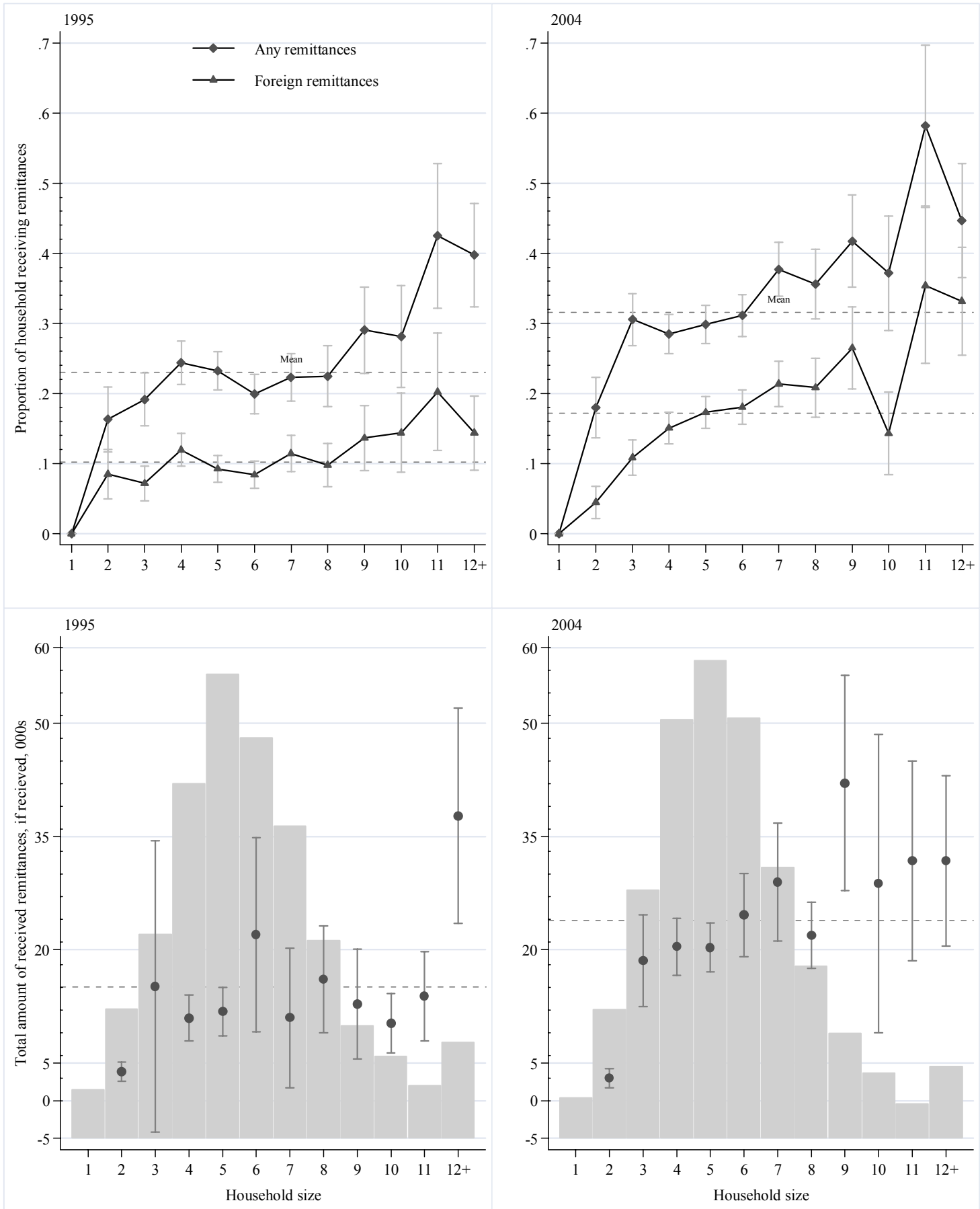

Figure 1: Incidence of migration and amount of remittances by the household size. Whiskers indicate $95 \%$ confidence intervals for the means. Histogram of the household size on the background of the lower two panels. NLSS 1995 and 2004 

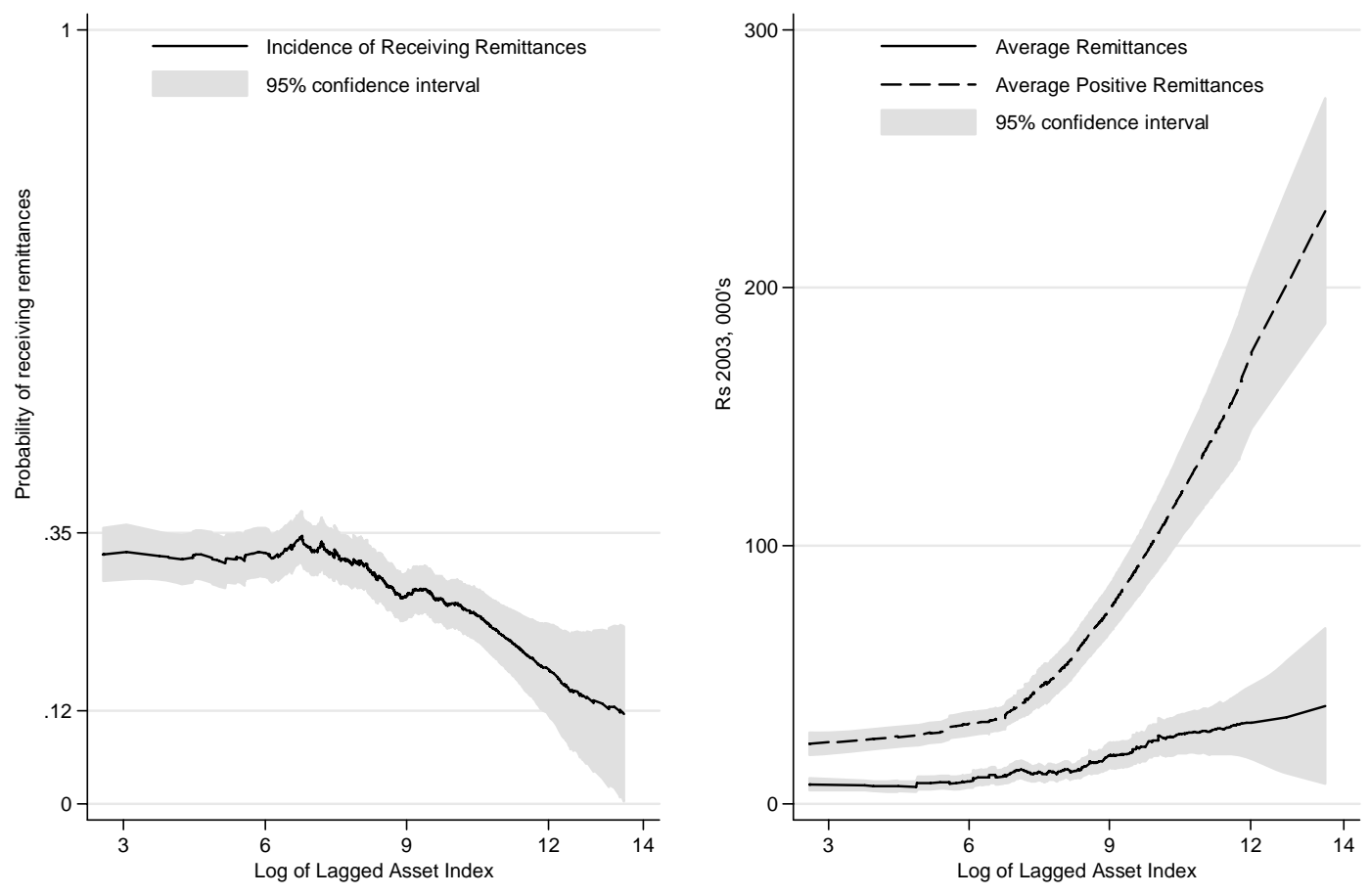

Figure 2: Non-parametric regression of the incidence of migration and amount of remittances by lagged asset index, NLSS 2004 

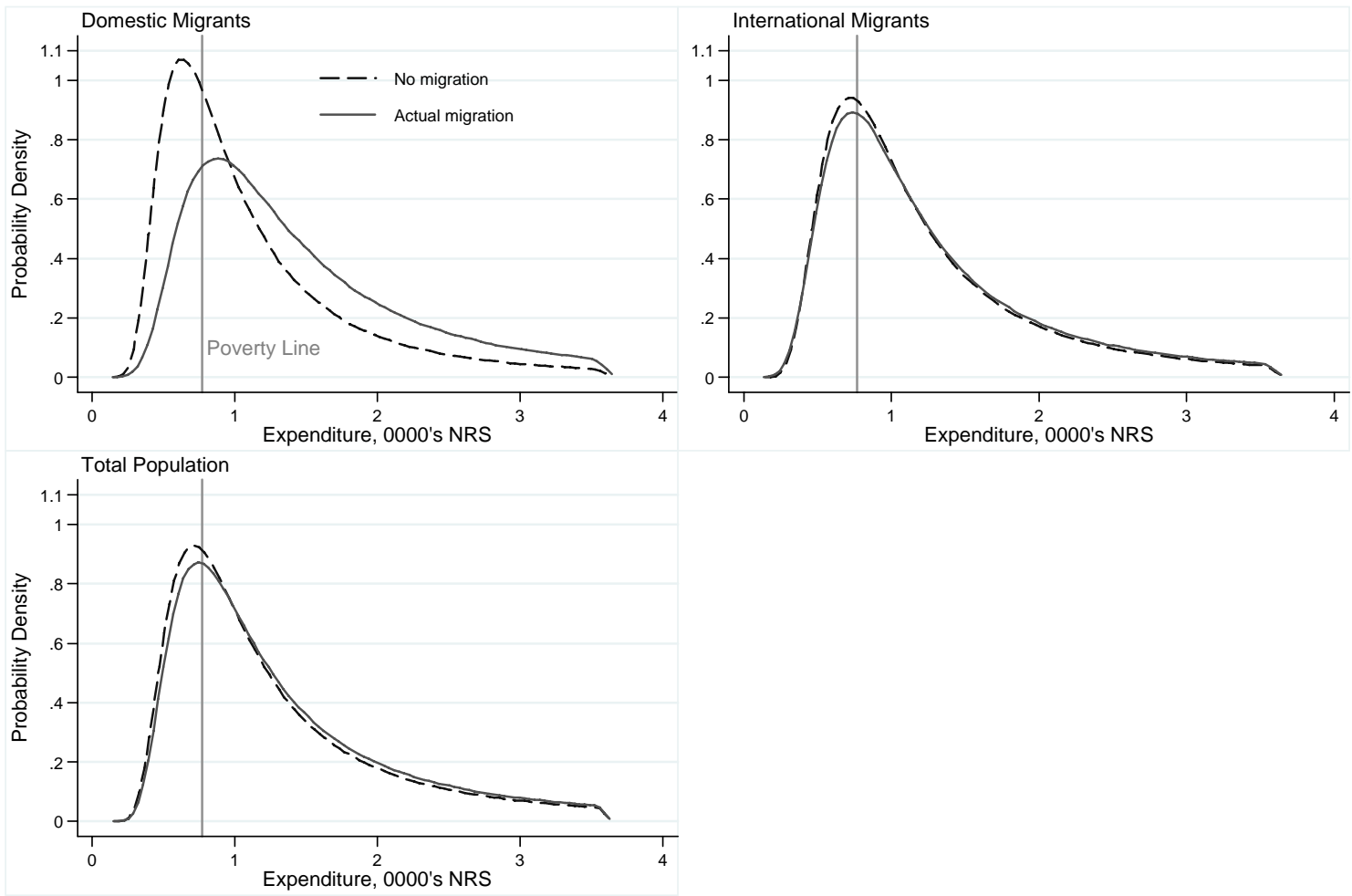

Figure 3: Simulated distributions of per capita household expenditure in the scenarios of the actual and of no migration by household migration status. 


\section{Appendix 1: The Likelihood function}

The condition (3) could be expressed in terms of value functions representing the pairwise differences of utility functions (2). Define:

$$
\begin{aligned}
& V_{i 1}=U_{i 1}-U_{i 3}=Z_{i}\left(\gamma_{1}-\gamma_{3}\right)+\eta_{i 1}-\eta_{i 3}=Z_{i} \varphi_{1}+\varepsilon_{i 1} \\
& V_{i 2}=U_{i 2}-U_{i 3}=Z_{i}\left(\gamma_{2}-\gamma_{3}\right)+\eta_{i 2}-\eta_{i 3}=Z_{i} \varphi_{2}+\varepsilon_{i 2}
\end{aligned}
$$

where $\varphi_{1,2}$ are the unknown parameters and $\varepsilon_{1,2}$ are i.i.d. error terms. Migration choices and corresponding consumption outcome are observed if:

$$
\begin{array}{lll}
\text { State }=1 \text { if } V_{i 1} \succ V_{i 2}, & & V_{i 1} \succ 0 ; C_{i 1}=X_{i} \beta_{1}+\mu_{i 1} \\
\text { State }=2 \text { if } V_{i 2} \succ V_{1}, & & V_{i 2} \succ 0 ; C_{i 2}=X_{i} \beta_{2}+\mu_{i 2} \\
\text { State }=3 \text { if } V_{i 1} \prec 0, & & V_{i 2} \prec 0 ; C_{i 3}=X_{i} \beta_{3}+\mu_{i 3}
\end{array}
$$

Assume that all the random variables in the model are distributed as five-variate normal, with the following variance-covariance matrix.

$$
f\left(\varepsilon_{1}, \varepsilon_{2}, \mu_{1}, \mu_{2}, \mu_{3}\right) \approx N(0, \Omega) ; \Omega=\left(\begin{array}{ccccc}
1 & \alpha & \sigma_{11} & \sigma_{12} & \sigma_{13} \\
& 1 & \sigma_{21} & \sigma_{22} & \sigma_{23} \\
& & s_{11} & s_{12} & s_{13} \\
& & & s_{22} & s_{23} \\
& & & & s_{33}
\end{array}\right)
$$

where $\alpha$ is a covariance between $\varepsilon_{1}$ and $\varepsilon_{2} ; \sigma$ 's are covariances between $\varepsilon_{1}, \varepsilon_{2}$ and consumption error terms $\mu_{1}, \mu_{2}, \mu_{3}$; and $s$ 's are covariances between $\mu_{1}, \mu_{2}, \mu_{3}$. For identification, both variances of the errors in (1) are normalized to 1 . The covariances $s_{12}$, $s_{13}$, and $s_{23}$ are not estimated as we never observe a household's consumption simultaneously in two distinct migration states.

The probability of observing a particular consumption outcome at a certain migration state can be decomposed into the product of conditional and unconditional probabilities:

$$
L_{i}^{k}=P\left(\text { State }=k, C_{i k}=X_{i} \beta_{k}+\mu_{i k}\right)=P\left(\text { State }=k \mid \mu_{i k}\right) \cdot P\left(\mu_{i k}\right)
$$

The unconditional part of (A.4) is the univariate normal density. After rescaling:

$$
P\left(\mu_{i k}=C_{i k}-X \beta_{i k}\right)=\varphi\left(\frac{C_{i k}-X_{i} \beta_{k}}{S_{k k}}\right)
$$

where $\varphi$ is standard normal density function. The conditional part of (A.4), for example for a household choosing state 1, can be expressed as: 


$$
\begin{aligned}
& P\left(\text { State }=1 \mid \mu_{i 1}\right)=P\left(V_{i 1} \succ U_{i 2}, V_{i 1} \succ 0 \mid \mu_{i 1}\right)= \\
& \mid \text { Substituting: } \eta_{i 1}^{1}=\varepsilon_{i 2}-\varepsilon_{i 1}, \eta_{i 2}^{1}=-\varepsilon_{i 1} \mid=P\left(\eta_{i 1}^{1} \prec Z_{i} \varphi_{1}-Z_{i} \varphi_{2}, \eta_{i 2}^{1} \prec Z \varphi_{i 1} \mid \mu_{i 1}\right)
\end{aligned}
$$

where $\eta_{1}^{j}$ and $\eta_{2}^{j}$ are distributed as:

$$
f\left(\eta_{1}^{1}, \eta_{2}^{1} \mid \mu_{1}\right) \approx N\left(\left(\begin{array}{cc}
\frac{\left(\sigma_{21}-\sigma_{11}\right) \mu_{1}}{s_{11}} \\
\frac{-\sigma_{11} \mu_{1}}{s_{11}}
\end{array}\right),\left(\begin{array}{cc}
2-2 \alpha-\frac{\left(\sigma_{21}-\sigma_{11}\right)^{2}}{s_{11}} & 1-\alpha+\frac{\sigma_{11}\left(\sigma_{21}-\sigma_{11}\right)}{s_{11}} \\
s_{11} & 1-\frac{\sigma_{11}^{2}}{s_{11}}
\end{array}\right)\right)
$$

After normalization

$$
\tilde{\eta}_{i 1}^{1}=\frac{\eta_{i 1}^{1}-E\left(\eta_{i 1}^{1}\right)}{\sqrt{V\left(\eta_{i 1}^{1}\right)}}, \tilde{\eta}_{i 2}^{1}=\frac{\eta_{i 2}^{1}-E\left(\eta_{i 2}^{1}\right)}{\sqrt{V\left(\eta_{i 2}^{1}\right)}}, \rho_{1}=\operatorname{Cov}\left(\tilde{\eta}_{i 1}^{1}, \tilde{\eta}_{i 2}^{1}\right)
$$

(A.7) can be expressed as a standard bivariate normal:

$$
P\left(\text { State }=1 \mid \mu_{i 1}\right)=\Phi\left(\tilde{\eta}_{i 1}^{1}, \tilde{\eta}_{i 2}^{1}, \rho^{1}\right)
$$

Then, a contribution to the likelihood function of the observation $i$ in State $k$ is:

$$
L_{i}^{k}=\Phi\left(\tilde{\eta}_{i 1}^{k}, \tilde{\eta}_{i 2}^{k}, \rho^{k}\right) \phi\left(\frac{\mu_{i k}}{S_{k k}}\right), \quad k=1,2,3
$$

However, (A.9) and (A.10) are different in every state. Log likelihood is formed as the sum of individual log-likelihoods (A.10) over all observations and all states:

$$
L=\sum_{i} \sum_{k} \ln L_{i}^{k} I(\text { State }=k), \quad i=1 \ldots N, k=1,2,3
$$

where $I$ is an indicator function for a migration state. To improve the fit of our estimation we use the Box-Cox transformation of the continuous dependent variables in our model (Heckman and Sedlacek 1990). The "Box-Cox parameter" $\lambda=-0.4$ provides best fit in terms of minimization of the sum of square residuals of the continuous part of the model.

The log-likelihood function (A.11) is maximized using a standard NewtonRaphson algorithm of Maximum Likelihood procedure in Stata. The maximization routine relies on analytical gradient and analytical Hessian that we programmed to improve convergence properties and speed of the estimation. The performance of maximization algorithm is crucial for the jackknife simulations we conduct in the paper*.

\footnotetext{
* The Stata code that implements the Full Information Maximum Likelihood algorithm is available from authors on request.
} 


\section{Appendix 2: Simulation techniques}

We treat household expenditure as a random variable that comes from some distribution the parameters of which we estimate. This random variable is a sum of observed and unobserved components. The observed component is a product of household characteristics and the returns on these characteristics in a particular migration state. The unobserved component is determined by the choice of the migration state according to rules (A.1) and (A.2). We cannot recover the exact value of the unobserved component but can only estimate the parameters of the distribution of that component in each counterfactual state. We need to simulate the distribution of counterfactual expenditures in order to calculate the poverty and inequality measures in various counterfactual scenarios.

To simulate the expenditure distribution for each household in different states of migration we draw error terms $\varepsilon_{1}, \varepsilon_{2}, \mu_{1}, \mu_{2}, \mu_{3}$ from unconditional 5-variate normal distribution with the estimated variance-covariance matrix (A.3). In every draw $m$ household $i$ is assigned to a particular migration state $s$, according to rule (A.1 and A.2):

$$
U_{i s}-U_{i j}=\hat{\varphi}_{s j} Z_{i}+\varepsilon_{i(s j)}^{m}>0 ; U_{i s}-U_{i k}=\hat{\varphi}_{s k} Z_{i}+\varepsilon_{i(s k)}^{m}>0
$$

where $\hat{\varphi}_{s j, s k}$ are the estimated parameters as in (A.1) and $\varepsilon_{i(s j),(s k)}^{m}$ are the values of the error terms in draw $m$. The expenditure of household $i$ in draw $m$ is:

$$
C_{i s}^{m}=\hat{\beta}_{s} X_{i}+\mu_{i s}^{m}
$$

So, in every draw only migration choice is realized and the counterfactual expenditure derived for that choice. By repeating this process $M$ times for all households in our sample we generate the simulated expenditure distribution in all migrations states. Any distributional statistics could be calculated using this distribution. For example, the simulated poverty rate for households with migrants working outside Nepal in case of no abroad migration is:

$$
P^{A M}=\frac{\sum_{m=1}^{M} \sum_{i=1}^{N} I\left(X_{i} \hat{\beta}_{1}+\mu_{i 1}^{m}<P L, s_{i}^{m}=3\right)}{\sum_{m=1}^{M} \sum_{i=1}^{N} I\left(s_{i}^{m}=3\right)}
$$


where $N$ is a total number of households in the sample, $P L$ is the poverty line, and $I$ is an indicator function. The expressions for other measures of poverty and inequality could be derived in a similar way.

The actual calculation of these statistics is a bit more involved as we use a BoxCox transformation for the household expenditures in our estimation. We apply inverse of a Box-Cox transformation on the last stage of simulation to obtain poverty and inequality measures of a non-transform distribution. The later step is crucial for calculation of the measures of inequality and inequality sensitive poverty measures. The counterfactual poverty rates could be calculated on the transformed distribution as the Box-Cox transformation preserve the expenditure ranking.

The confidence intervals for poverty and inequality measures are estimated by the method of jackknife (e.g. Efron 1981). The jackknife estimate of the parameter $\theta$ is given by:

$$
\hat{\theta}_{J}=\frac{\sum_{i=1}^{n} \hat{\theta}_{(i)}}{n}
$$

The jackknife estimate of the standard error of $\hat{\theta}_{j}$ is

$$
\hat{\sigma}_{\hat{\theta}_{j}}=\left[\frac{n-1}{n} \sum_{i=1}^{n}\left(\hat{\theta}_{(i)}-\hat{\theta}_{J}\right)^{2}\right]^{1 / 2}
$$

where $n$ is the sample size, and $\hat{\theta}_{(1)}, \hat{\theta}_{(2)}, \ldots, \hat{\theta}_{(n)}$ are the estimates of $\theta$ on $n$ subsamples each of size $n-1$.

We repeat the simulation process based on 1000 draws for each jackknife iteration. We were not able to use a bootstrap to calculate the standard errors for our simulations because of the large number of non-convergences of our estimator on the bootstrapped samples. Efron (1981) demonstrates that the jackknife estimates of the standard errors are typically larger than the bootstrap estimates.

Figure A1 demonstrates how well our simulations fit the actual distribution of per capita consumption in the total population and in the subgroups of households with different migration status. Each graph on Figure A1 shows three cumulative distributions. The solid line presents the cumulative distribution of the actual per capita expenditures generated from our sample of 3,620 observations. The consumption distribution that is 
simulated using the estimated parameters of the system (1-3) and the estimated variancecovariance matrix (A3) is shown as a dash line. The counterfactual distribution simulated under scenario of no migration is shown as a dotted line.

Comparing the actual (solid line) and predicted (dash line) distributions for the total population demonstrates a reasonably good fit achieved by our simulations. The number of households with simulated expenditures below the poverty line is almost identical to the actual number of the poor households in our sample. The distribution simulated under scenario of no migration exhibits the first order dominance over the actual distributions. This indicates that relative to the actual consumption distribution the no-migration scenario would result in higher poverty rates regardless of the choice of the poverty line. Similar to results in Table 5, the no migration scenario has a largest negative impact for the consumption of households with domestic migrants.
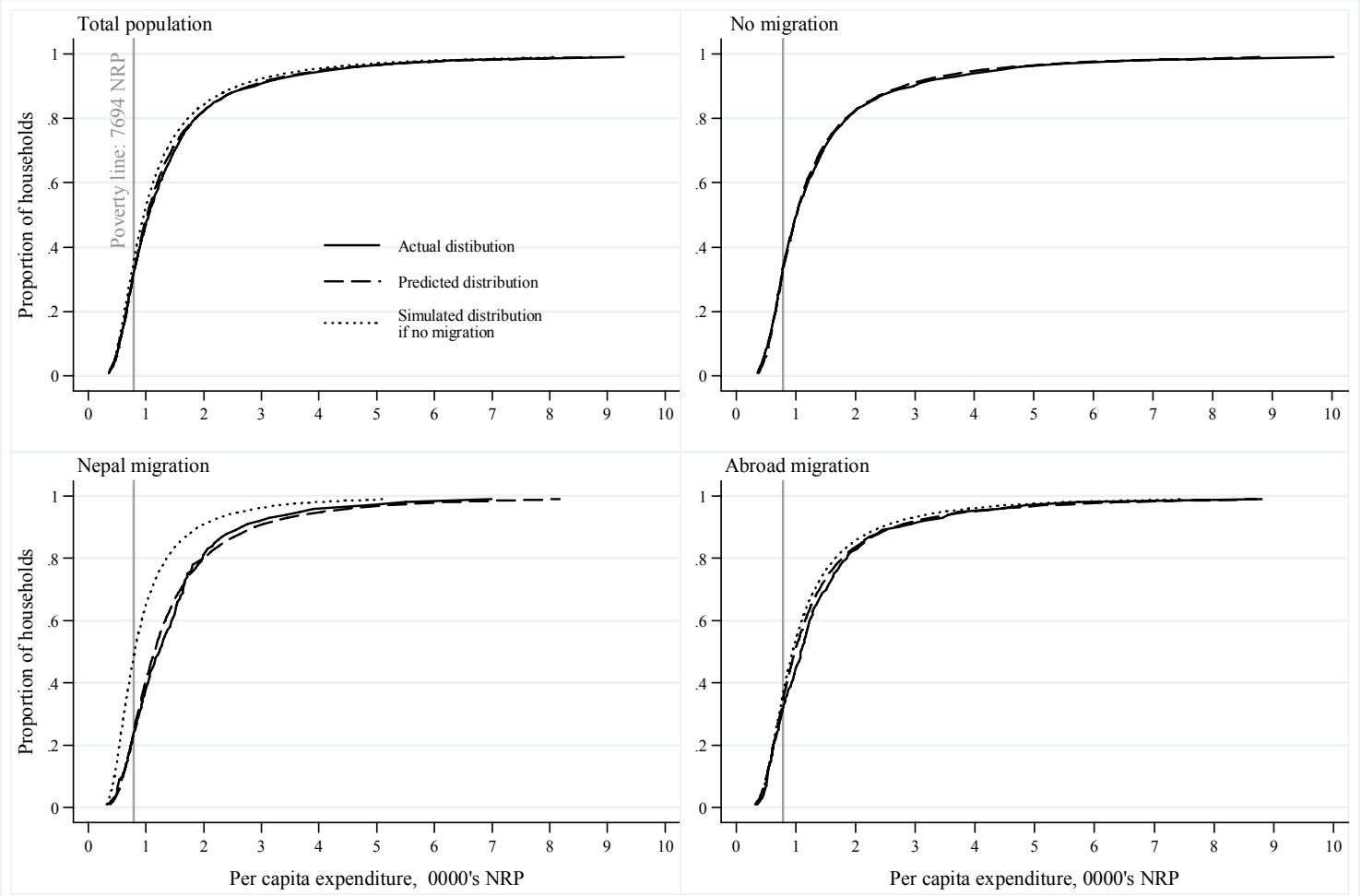

Figure A1: Actual, simulated actual and counterfactual expenditure distribution under scenario of no migration for households with domestic migrants, international migrants, no migrants, and the total population. 


\section{Appendix 3}

Table A3.1: Multinomial probit estimation of the migration choice in the system (2-4)

\begin{tabular}{|c|c|c|c|c|}
\hline \multirow[t]{2}{*}{ Base category: No Migration } & \multicolumn{2}{|c|}{ Domestic Migration } & \multicolumn{2}{|c|}{ International Migration } \\
\hline & Coefficient & Std. Error & Coefficient & Std. Error \\
\hline Share of domestic migrants in district, 1995 & $0.856^{*}$ & 0.439 & -0.747 & 0.471 \\
\hline Share of international migrants in a ward, 2001 & 0.191 & 0.324 & $1.761^{* * *}$ & 0.269 \\
\hline \multicolumn{5}{|l|}{ Household Demographics (before migration) } \\
\hline Household size & $0.221^{* * *}$ & 0.023 & $0.179^{* * *}$ & 0.022 \\
\hline \multicolumn{5}{|l|}{ Share of children 0-3: Omitted variable } \\
\hline Share of children $4-7$ & -0.288 & 0.523 & 0.224 & 0.466 \\
\hline Share of children $8-15$ & -0.022 & 0.380 & $-0.599^{*}$ & 0.350 \\
\hline Share of men $16-64$ & $1.501^{* * *}$ & 0.468 & 0.272 & 0.463 \\
\hline Share of women 16-64 & $2.876^{* * *}$ & 0.399 & $1.888^{* * *}$ & 0.376 \\
\hline Share of elderly & $4.334^{* * *}$ & 0.487 & $1.428^{* * *}$ & 0.505 \\
\hline Number of married couples & $-0.536^{* * *}$ & 0.073 & $-0.127^{*}$ & 0.069 \\
\hline Maximum education in the household & 0.019 & 0.036 & 0.033 & 0.035 \\
\hline \multicolumn{5}{|l|}{ Ethnicity: Reference Category: Brahman $\backslash$ Chhetri } \\
\hline Dalit & $-0.395^{* *}$ & 0.169 & 0.004 & 0.142 \\
\hline Newar & $-0.321^{* *}$ & 0.151 & $-0.634^{* * *}$ & 0.176 \\
\hline Terai-Hill Janajatis & $-0.223^{* *}$ & 0.105 & -0.160 & 0.102 \\
\hline Muslim $\backslash$ Other Minorities & $-0.364^{* * *}$ & 0.119 & -0.154 & 0.112 \\
\hline \multicolumn{5}{|c|}{ Land holdings a year ago: Reference Category: No farm plot } \\
\hline Farm plot $<0.5$ ha & -0.082 & 0.111 & 0.046 & 0.109 \\
\hline Farm plot $0.5-1$ ha & $-0.375^{* * *}$ & 0.135 & -0.144 & 0.129 \\
\hline Farm plot: $1-2$ ha & -0.236 & 0.150 & -0.042 & 0.144 \\
\hline Farm plot $>2$ ha & -0.251 & 0.186 & -0.264 & 0.185 \\
\hline \multicolumn{5}{|c|}{ Lagged durable asset index: Reference Category: No durables } \\
\hline Asset poor $\left(1-33^{\text {th }}\right.$ percentile $)$ & 0.085 & 0.103 & $-0.185^{*}$ & 0.101 \\
\hline$\left(33^{\text {th }}-66^{\text {th }}\right.$ percentile $)$ & -0.062 & 0.110 & $-0.185^{*}$ & 0.105 \\
\hline Asset rich $\left(66^{\text {th }}-100^{\text {th }}\right.$ percentile $)$ & $-0.471^{* * *}$ & 0.136 & -0.189 & 0.129 \\
\hline Total pensions per capita & -0.022 & 0.017 & $0.023^{* *}$ & 0.012 \\
\hline \multicolumn{5}{|l|}{ Geography dummies: Reference Category: Katmandu } \\
\hline Other urban areas & $0.975^{* * *}$ & 0.206 & $0.805^{* * *}$ & 0.220 \\
\hline Rural west mount/hills & $0.774^{* * *}$ & 0.267 & $1.476^{* * *}$ & 0.273 \\
\hline Rural eastern mount/hills & $0.778^{* * *}$ & 0.245 & $0.676^{* * *}$ & 0.261 \\
\hline Rural western Terai & $0.898^{* * *}$ & 0.261 & $1.050^{* * *}$ & 0.268 \\
\hline Rural eastern Terai & $1.146^{* * *}$ & 0.237 & $1.196^{* * *}$ & 0.248 \\
\hline Log of distance to market center & -0.062 & 0.038 & -0.023 & 0.036 \\
\hline \multicolumn{5}{|l|}{ Ward level variables } \\
\hline$\%$ illiterate, among age $15+$ & -0.639 & 0.448 & 0.102 & 0.435 \\
\hline$\%$ literate or $1-4$ years of education & -0.509 & 0.658 & 0.700 & 0.636 \\
\hline$\%$ completed 5-7 years of education & -0.293 & 0.726 & 0.637 & 0.697 \\
\hline$\%$ employed in wage job & -0.221 & 0.513 & 0.669 & 0.444 \\
\hline$\%$ self employed & $0.783^{* *}$ & 0.307 & -0.045 & 0.281 \\
\hline Log of average household expenditure, 1995 & 0.102 & 0.155 & 0.194 & 0.149 \\
\hline Gini coefficient, 1995 & -0.191 & 0.662 & $-1.304^{* *}$ & 0.616 \\
\hline Casualties from conflict, district level & -0.034 & 0.077 & -0.041 & 0.067 \\
\hline Constant & $-4.511^{* * *}$ & 1.502 & $-5.139^{* * *}$ & 1.449 \\
\hline Number of observ & \\
\hline Log-Likelihood & \multicolumn{4}{|c|}{$-2,705.19$} \\
\hline
\end{tabular}

Note: ${ }^{*}$ is significant at $10 \%$ level; ${ }^{* *}$ at $5 \%$ level; ${ }^{* * *}$ at $1 \%$ level; ${ }^{*}$ indicates joint significance of coefficients at $10 \%$ level. 
Table A4.1: OLS estimation of expenditure equations of the system (2-4)

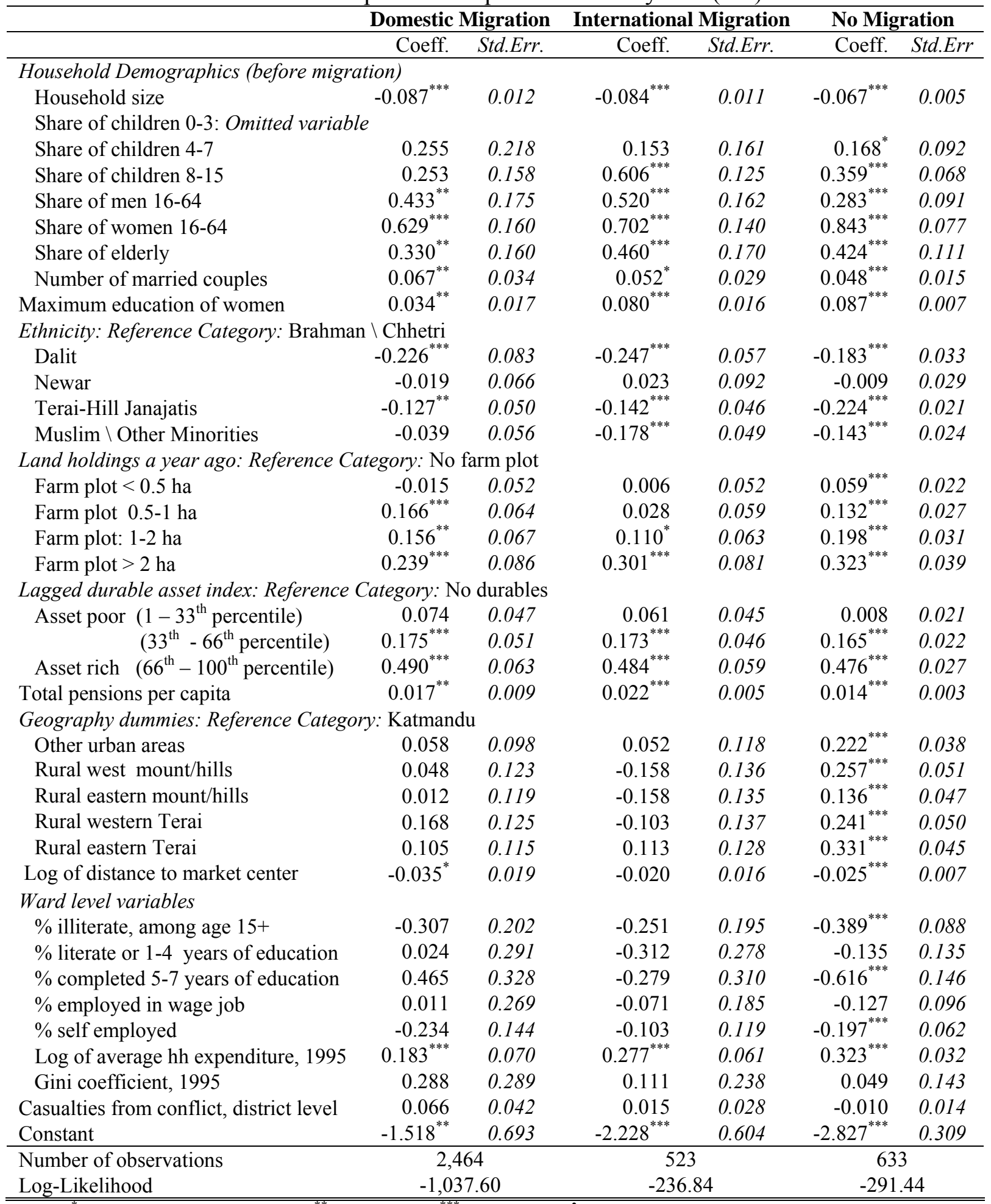

Note: ${ }^{*}$ is significant at $10 \%$ level; ${ }^{* *}$ at $5 \%$ level; ${ }^{* * *}$ at $1 \%$ level; ${ }^{*}$ indicates joint significance of coefficients at $10 \%$ level. 
Table A3.2: FIML estimation of the migration choice part of the system (2-4) with amounts of remittances.

\begin{tabular}{|c|c|c|c|c|}
\hline \multirow[t]{2}{*}{ Base category: No Migration } & \multicolumn{2}{|c|}{ Domestic Migration } & \multicolumn{2}{|c|}{ International Migration } \\
\hline & Coefficient & Std. Error & Coefficient & Std. Error \\
\hline Share of domestic migrants in district, 1995 & $0.978^{* * *}$ & 0.298 & -0.463 & 0.336 \\
\hline Share of international migrants in a ward, 2001 & 0.192 & 0.230 & $1.260^{* * *}$ & 0.193 \\
\hline \multicolumn{5}{|l|}{ Household Demographics (before migration) } \\
\hline Household size & $0.159^{* * *}$ & 0.017 & $0.127^{* * *}$ & 0.016 \\
\hline \multicolumn{5}{|l|}{ Share of children 0-3: Omitted variable } \\
\hline Share of children $4-7$ & -0.174 & 0.373 & 0.172 & 0.330 \\
\hline Share of children $8-15$ & -0.020 & 0.273 & $-0.415^{*}$ & 0.248 \\
\hline Share of men $16-64$ & $1.222^{* * *}$ & 0.336 & 0.259 & 0.331 \\
\hline Share of women 16-64 & $1.990^{* * *}$ & 0.286 & $1.316^{* * *}$ & 0.266 \\
\hline Share of elderly & $3.044^{* * *}$ & 0.343 & $1.004^{* * *}$ & 0.356 \\
\hline Number of married couples & $-0.383^{* * *}$ & 0.052 & $-0.093^{*}$ & 0.049 \\
\hline Maximum education in the household & 0.001 & 0.026 & 0.020 & 0.025 \\
\hline \multicolumn{5}{|l|}{ Ethnicity: Reference Category: Brahman $\backslash$ Chhetri } \\
\hline Dalit & $-0.275^{* *}$ & 0.119 & 0.002 & 0.100 \\
\hline Newar & $-0.247^{* *}$ & 0.106 & $-0.451^{* * *}$ & 0.124 \\
\hline Terai-Hill Janajatis & $-0.159^{* *}$ & 0.075 & -0.112 & 0.072 \\
\hline Muslim $\backslash$ Other Minorities & $-0.271^{* * *}$ & 0.085 & -0.108 & 0.079 \\
\hline \multicolumn{5}{|c|}{ Land holdings a year ago: Reference Category: No farm plot } \\
\hline Farm plot $<0.5$ ha & -0.061 & 0.078 & 0.034 & 0.077 \\
\hline Farm plot $0.5-1$ ha & $-0.255^{* * *}$ & 0.095 & -0.102 & 0.091 \\
\hline Farm plot: $1-2$ ha & -0.147 & 0.107 & -0.025 & 0.102 \\
\hline Farm plot $>2$ ha & -0.167 & 0.132 & -0.186 & 0.131 \\
\hline \multicolumn{5}{|c|}{ Lagged durable asset index: Reference Category: No durables } \\
\hline Asset poor $\left(1-33^{\text {th }}\right.$ percentile $)$ & 0.057 & 0.073 & $-0.132^{*}$ & 0.071 \\
\hline$\left(33^{\text {th }}-66^{\text {th }}\right.$ percentile $)$ & -0.052 & 0.077 & $-0.133^{*}$ & 0.074 \\
\hline Asset rich $\left(66^{\text {th }}-100^{\text {th }}\right.$ percentile $)$ & $-0.321^{* * *}$ & 0.096 & -0.133 & 0.091 \\
\hline Total pensions per capita & -0.015 & 0.012 & $0.016^{*}$ & 0.008 \\
\hline \multicolumn{5}{|l|}{ Geography dummies: Reference Category: Katmandu } \\
\hline Other urban areas & $0.690^{* * *}$ & 0.145 & $0.565^{* * *}$ & 0.155 \\
\hline Rural west mount/hills & $0.533^{* * *}$ & 0.188 & $1.033^{* * *}$ & 0.193 \\
\hline Rural eastern mount/hills & $0.555^{* * *}$ & 0.173 & $0.473^{* *}$ & 0.184 \\
\hline Rural western Terai & $0.631^{* * *}$ & 0.184 & $0.735^{* * *}$ & 0.190 \\
\hline Rural eastern Terai & $0.791^{* * *}$ & 0.167 & $0.834^{* * *}$ & 0.175 \\
\hline Log of distance to market center & -0.041 & 0.027 & -0.015 & 0.025 \\
\hline \multicolumn{5}{|l|}{ Ward level variables } \\
\hline$\%$ illiterate, among age $15+$ & $-0.528^{*}$ & 0.313 & 0.054 & 0.308 \\
\hline$\%$ literate or $1-4$ years of education & -0.488 & 0.464 & 0.471 & 0.452 \\
\hline$\%$ completed $5-7$ years of education & -0.206 & 0.511 & 0.453 & 0.492 \\
\hline$\%$ employed in wage job & -0.066 & 0.359 & 0.486 & 0.314 \\
\hline$\%$ self employed & $0.555^{* *}$ & 0.216 & -0.024 & 0.199 \\
\hline Log of average hh expenditure, 1995 & 0.065 & 0.108 & 0.135 & 0.105 \\
\hline Gini coefficient, 1995 & -0.033 & 0.466 & $-0.925^{* *}$ & 0.435 \\
\hline Casualties from conflict, district level & -0.024 & 0.053 & -0.031 & 0.047 \\
\hline Constant & $-3.186^{* * *}$ & 1.052 & $-3.618^{* * *}$ & 1.023 \\
\hline Number of observations & & & & \\
\hline Log-Likelihood & & & & \\
\hline
\end{tabular}

Note: ${ }^{*}$ is significant at $10 \%$ level; ${ }^{* *}$ at $5 \%$ level; ${ }^{* * *}$ at $1 \%$ level; ${ }^{*}$ indicates joint significance of coefficients at $10 \%$ level. 
Table A4.2: FIML estimation of expenditure equations of the system (2-4) with amounts.

\begin{tabular}{|c|c|c|c|c|c|c|}
\hline & \multicolumn{2}{|c|}{ Domestic Migration } & \multicolumn{2}{|c|}{ International Migration } & \multicolumn{2}{|c|}{ No Migration } \\
\hline & Coeff. & Std.Err. & Coeff. & Std.Err. & Coeff. & Std.Err \\
\hline Log amount of remittances & $0.061^{* * *}$ & 0.012 & $0.118^{* * *}$ & 0.011 & & \\
\hline \multicolumn{7}{|c|}{ Household Demographics (before migration) } \\
\hline Household size & $-0.102^{* * *}$ & 0.015 & $-0.053^{* * *}$ & 0.015 & $-0.073^{* * *}$ & 0.007 \\
\hline \multicolumn{7}{|l|}{ Share of children 0-3: Omitted variable } \\
\hline Share of children $4-7$ & 0.244 & 0.210 & 0.102 & 0.148 & $0.174^{*}$ & 0.093 \\
\hline Share of children $8-15$ & 0.249 & 0.154 & $0.536^{* * *}$ & 0.115 & $0.357^{* * *}$ & 0.069 \\
\hline Share of men $16-64$ & 0.121 & 0.189 & $0.528^{* * *}$ & 0.174 & $0.228^{* *}$ & 0.095 \\
\hline Share of women 16-64 & $0.307^{*}$ & 0.182 & $0.771^{* * *}$ & 0.180 & $0.753^{* * *}$ & 0.092 \\
\hline Share of elderly & -0.178 & 0.212 & $0.455^{* *}$ & 0.228 & $0.264^{*}$ & 0.135 \\
\hline Number of married couples & $0.121^{* * *}$ & 0.041 & 0.030 & 0.035 & $0.067^{* * *}$ & 0.018 \\
\hline Maximum education of women & 0.025 & 0.017 & $0.071^{* * *}$ & 0.014 & $0.086^{* * *}$ & 0.007 \\
\hline \multicolumn{7}{|c|}{ Ethnicity: Reference Category: Brahman $\backslash$ Chhetri } \\
\hline Dalit & $-0.142^{*}$ & 0.086 & $-0.200^{* * *}$ & 0.056 & $-0.170^{* * *}$ & 0.033 \\
\hline Newar & 0.065 & 0.069 & 0.007 & 0.090 & -0.002 & 0.031 \\
\hline Terai-Hill Janajatis & -0.075 & 0.051 & $-0.164^{* * *}$ & 0.043 & $-0.218^{* * *}$ & 0.022 \\
\hline Muslim $\backslash$ Other Minorities & 0.030 & 0.057 & $-0.141^{* * *}$ & 0.048 & $-0.133^{* * *}$ & 0.025 \\
\hline \multicolumn{7}{|c|}{ Land holdings a year ago: Reference Category: No farm plot } \\
\hline Farm plot $<0.5$ ha & -0.016 & 0.051 & -0.036 & 0.047 & $0.062^{* * *}$ & 0.022 \\
\hline Farm plot $0.5-1$ ha & $0.187^{* * *}$ & 0.064 & -0.026 & 0.057 & $0.143^{* * *}$ & 0.028 \\
\hline Farm plot: $1-2$ ha & $0.167^{* *}$ & 0.067 & 0.053 & 0.060 & $0.206^{* * *}$ & 0.032 \\
\hline Farm plot $>2$ ha & $0.248^{* * *}$ & 0.085 & $0.220^{* * *}$ & 0.075 & $0.330^{* * *}$ & 0.040 \\
\hline \multicolumn{7}{|c|}{ Lagged durable asset index: Reference Category: No durables } \\
\hline Asset poor $\left(1-33^{\text {th }}\right.$ percentile $)$ & 0.054 & 0.049 & 0.041 & 0.044 & 0.004 & 0.021 \\
\hline$\left(33^{\text {th }}-66^{\text {th }}\right.$ percentile $)$ & $0.161^{* * *}$ & 0.050 & $0.121^{* * *}$ & 0.043 & $0.166^{* * *}$ & 0.023 \\
\hline Asset rich $\left(66^{\text {th }}-100^{\text {th }}\right.$ percentile $)$ & $0.518^{* * *}$ & 0.065 & $0.392^{* * *}$ & 0.059 & $0.490^{* * *}$ & 0.028 \\
\hline Total pensions per capita & $0.020^{* *}$ & 0.009 & $0.022^{* * *}$ & 0.005 & $0.015^{* * *}$ & 0.003 \\
\hline \multicolumn{7}{|c|}{ Geography dummies: Reference Category: Katmandu } \\
\hline Other urban areas & -0.098 & 0.105 & 0.109 & 0.125 & $0.196^{* * *}$ & 0.041 \\
\hline Rural west mount/hills & -0.064 & 0.134 & -0.008 & 0.161 & $0.242^{* * *}$ & 0.059 \\
\hline Rural eastern mount/hills & -0.063 & 0.119 & -0.083 & 0.131 & $0.116^{* *}$ & 0.048 \\
\hline Rural western Terai & 0.037 & 0.128 & -0.027 & 0.141 & $0.220^{* * *}$ & 0.053 \\
\hline Rural eastern Terai & -0.066 & 0.122 & 0.149 & 0.138 & $0.301^{* * *}$ & 0.049 \\
\hline Log of distance to market center & -0.025 & 0.018 & -0.024 & 0.015 & $-0.023^{* * *}$ & 0.008 \\
\hline \multicolumn{7}{|l|}{ Ward level variables } \\
\hline$\%$ illiterate, among age $15+$ & -0.154 & 0.201 & -0.158 & 0.185 & $-0.370^{* * *}$ & 0.089 \\
\hline$\%$ literate or $1-4$ years of education & 0.099 & 0.290 & -0.150 & 0.265 & -0.118 & 0.136 \\
\hline$\%$ completed 5-7 years of education & $0.568^{*}$ & 0.324 & -0.167 & 0.286 & $-0.603^{* * *}$ & 0.148 \\
\hline$\%$ employed in wage job & 0.077 & 0.263 & 0.027 & 0.169 & -0.117 & 0.098 \\
\hline$\%$ self employed & $-0.364^{* *}$ & 0.144 & -0.062 & 0.116 & $-0.222^{* * *}$ & 0.064 \\
\hline Log of average hh expenditure, 1995 & $0.136^{*}$ & 0.070 & $0.176^{* * *}$ & 0.057 & $0.320^{* * *}$ & 0.032 \\
\hline Gini coefficient, 1995 & 0.267 & 0.289 & 0.160 & 0.224 & 0.054 & 0.144 \\
\hline Casualties from conflict, district level & $0.091^{* *}$ & 0.040 & 0.016 & 0.027 & -0.009 & 0.014 \\
\hline Constant & -0.537 & 0.738 & $-1.914^{* * *}$ & 0.649 & $-2.783^{* * *}$ & 0.314 \\
\hline Number of observations & & & 3620 & & & \\
\hline Log-Likelihood & & & $-4,202$ & & & \\
\hline
\end{tabular}

Note: ${ }^{*}$ is significant at $10 \%$ level; ${ }^{* *}$ at $5 \%$ level; ${ }^{* * *}$ at $1 \%$ level; ${ }^{*}$ indicates joint significance of coefficients at $10 \%$ level. 
Table A3.3: FIML estimation of the migration choice part of the system (2-4) with amounts of remittances instrumented by age of the migrant.

\begin{tabular}{|c|c|c|c|c|}
\hline \multirow[t]{2}{*}{ Base category: No Migration } & \multicolumn{2}{|c|}{ Domestic Migration } & \multicolumn{2}{|c|}{ International Migration } \\
\hline & Coefficient & Std. Error & Coefficient & Std. Error \\
\hline Share of domestic migrants in district, 1995 & $1.051^{* * *}$ & 0.287 & -0.421 & 0.334 \\
\hline Share of international migrants in a ward, 2001 & 0.174 & 0.228 & $1.273^{* * *}$ & 0.191 \\
\hline \multicolumn{5}{|l|}{ Household Demographics (before migration) } \\
\hline Household size & $0.158^{* * *}$ & 0.017 & $0.127^{* * *}$ & 0.016 \\
\hline \multicolumn{5}{|l|}{ Share of children 0-3: Omitted variable } \\
\hline Share of children $4-7$ & -0.192 & 0.372 & 0.164 & 0.330 \\
\hline Share of children $8-15$ & -0.056 & 0.273 & $-0.416^{*}$ & 0.248 \\
\hline Share of men $16-64$ & $1.171^{* * *}$ & 0.332 & 0.244 & 0.329 \\
\hline Share of women 16-64 & $1.987^{* * *}$ & 0.284 & $1.310^{* * *}$ & 0.265 \\
\hline Share of elderly & $2.970^{* * *}$ & 0.346 & $0.946^{* * *}$ & 0.357 \\
\hline Number of married couples & $-0.379^{* * *}$ & 0.051 & $-0.089^{*}$ & 0.049 \\
\hline Maximum education in the household & 0.004 & 0.026 & 0.023 & 0.025 \\
\hline \multicolumn{5}{|l|}{ Ethnicity: Reference Category: Brahman $\backslash$ Chhetri } \\
\hline Dalit & $-0.269^{* *}$ & 0.119 & 0.018 & 0.101 \\
\hline Newar & $-0.245^{* *}$ & 0.106 & $-0.452^{* * *}$ & 0.124 \\
\hline Terai-Hill Janajatis & $-0.161^{* *}$ & 0.074 & -0.108 & 0.072 \\
\hline Muslim $\backslash$ Other Minorities & $-0.280^{* * *}$ & 0.085 & -0.105 & 0.080 \\
\hline \multicolumn{5}{|c|}{ Land holdings a year ago: Reference Category: No farm plot } \\
\hline Farm plot $<0.5$ ha & -0.061 & 0.078 & 0.036 & 0.077 \\
\hline Farm plot $0.5-1$ ha & $-0.248^{* * *}$ & 0.096 & -0.099 & 0.091 \\
\hline Farm plot: $1-2$ ha & -0.144 & 0.107 & -0.028 & 0.102 \\
\hline Farm plot $>2$ ha & -0.157 & 0.132 & -0.190 & 0.132 \\
\hline \multicolumn{5}{|c|}{ Lagged durable asset index: Reference Category: No durables } \\
\hline Asset poor $\left(1-33^{\text {th }}\right.$ percentile $)$ & 0.057 & 0.073 & $-0.134^{*}$ & 0.071 \\
\hline$\left(33^{\text {th }}-66^{\text {th }}\right.$ percentile $)$ & -0.056 & 0.077 & $-0.140^{*}$ & 0.075 \\
\hline Asset rich $\left(66^{\text {th }}-100^{\text {th }}\right.$ percentile $)$ & $-0.324^{* * *}$ & 0.096 & -0.138 & 0.091 \\
\hline Total pensions per capita & -0.015 & 0.012 & $0.016^{*}$ & 0.008 \\
\hline \multicolumn{5}{|l|}{ Geography dummies: Reference Category: Katmandu } \\
\hline \multicolumn{5}{|l|}{ Other urban areas } \\
\hline Rural west mount/hills & $0.700^{* * *}$ & 0.145 & $0.566^{* * *}$ & 0.155 \\
\hline Rural eastern mount/hills & $0.556^{* * *}$ & 0.190 & $1.040^{* * *}$ & 0.193 \\
\hline Rural western Terai & $0.570^{* * *}$ & 0.173 & $0.479^{* * *}$ & 0.184 \\
\hline Rural eastern Terai & $0.650^{* * *}$ & 0.184 & $0.739^{* * *}$ & 0.189 \\
\hline Log of distance to market center & $0.804^{* * *}$ & 0.167 & $0.839^{* * *}$ & 0.175 \\
\hline Ward level variables & -0.041 & 0.027 & -0.015 & 0.025 \\
\hline$\%$ illiterate, among age $15+$ & $-0.544^{*}$ & 0.312 & 0.031 & 0.307 \\
\hline$\%$ literate or $1-4$ years of education & -0.550 & 0.463 & 0.417 & 0.448 \\
\hline$\%$ completed $5-7$ years of education & -0.198 & 0.511 & 0.413 & 0.495 \\
\hline$\%$ employed in wage job & -0.053 & 0.358 & 0.484 & 0.315 \\
\hline$\%$ self employed & $0.550^{* *}$ & 0.216 & -0.031 & 0.199 \\
\hline Log of average hh expenditure, 1995 & 0.063 & 0.108 & 0.132 & 0.105 \\
\hline Gini coefficient, 1995 & 0.014 & 0.464 & $-0.917^{* *}$ & 0.436 \\
\hline Casualties from conflict, district level & -0.024 & 0.053 & -0.035 & 0.048 \\
\hline Constant & $-3.164^{* * *}$ & 1.048 & $-3.564^{* * *}$ & 1.023 \\
\hline Number of observations & & & & \\
\hline Log-Likelihood & & & & \\
\hline
\end{tabular}

Note: ${ }^{*}$ is significant at $10 \%$ level; ${ }^{* *}$ at $5 \%$ level; ${ }^{* * *}$ at $1 \%$ level; ${ }^{*}$ indicates joint significance of coefficients at $10 \%$ level. 
Table A4.3: FIML estimation of expenditure equations of the system (2-4) with amounts of remittances instrumented by age of the migrant.

\begin{tabular}{|c|c|c|c|c|c|c|}
\hline & \multicolumn{2}{|c|}{ Domestic Migration } & \multicolumn{2}{|c|}{ International Migration } & \multicolumn{2}{|c|}{ No Migration } \\
\hline & Coeff. & Std.Err. & Coeff. & Std.Err. & Coeff. & Std.Err \\
\hline Log amount of remittances & 0.015 & 0.042 & 0.059 & 0.052 & & \\
\hline \multicolumn{7}{|c|}{ Household Demographics (before migration) } \\
\hline Household size & $-0.117^{* * *}$ & 0.017 & $-0.085^{* * *}$ & 0.022 & $-0.074^{* * *}$ & 0.006 \\
\hline \multicolumn{7}{|l|}{ Share of children 0-3: Omitted variable } \\
\hline Share of children $4-7$ & 0.306 & 0.220 & 0.103 & 0.164 & $0.175^{*}$ & 0.093 \\
\hline Share of children 8-15 & $0.275^{*}$ & 0.159 & $0.582^{* * *}$ & 0.127 & $0.358^{* * *}$ & 0.069 \\
\hline Share of men 16-64 & 0.148 & 0.191 & $0.402^{* *}$ & 0.192 & $0.228^{* *}$ & 0.094 \\
\hline Share of women 16-64 & 0.278 & 0.181 & $0.535^{* *}$ & 0.223 & $0.749^{* * *}$ & 0.091 \\
\hline Share of elderly & -0.190 & 0.203 & 0.245 & 0.249 & $0.261^{* *}$ & 0.132 \\
\hline Number of married couples & $0.146^{* * *}$ & 0.042 & 0.063 & 0.040 & $0.067^{* * *}$ & 0.018 \\
\hline Maximum education of women & $0.032^{*}$ & 0.018 & $0.076^{* * *}$ & 0.016 & $0.086^{* * *}$ & 0.007 \\
\hline \multicolumn{7}{|c|}{ Ethnicity: Reference Category: Brahman \Chhetri } \\
\hline Dalit & $-0.147^{*}$ & 0.089 & $-0.217^{* * *}$ & 0.060 & $-0.170^{* * *}$ & 0.033 \\
\hline Newar & 0.054 & 0.071 & 0.073 & 0.101 & -0.002 & 0.031 \\
\hline Terai-Hill Janajatis & -0.074 & 0.053 & $-0.136^{* * *}$ & 0.048 & $-0.218^{* * *}$ & 0.022 \\
\hline Muslim $\backslash$ Other Minorities & 0.026 & 0.059 & $-0.133^{* *}$ & 0.054 & $-0.132^{* * *}$ & 0.025 \\
\hline \multicolumn{7}{|c|}{ Land holdings a year ago: Reference Category: No farm plot } \\
\hline Farm plot $<0.5$ ha & -0.004 & 0.053 & -0.016 & 0.055 & $0.062^{* * *}$ & 0.022 \\
\hline Farm plot $0.5-1$ ha & $0.209^{* * *}$ & 0.068 & 0.025 & 0.067 & $0.143^{* * *}$ & 0.028 \\
\hline Farm plot: $1-2$ ha & $0.178^{* *}$ & 0.070 & 0.089 & 0.069 & $0.206^{* * *}$ & 0.032 \\
\hline Farm plot $>2$ ha & $0.260^{* * *}$ & 0.089 & $0.281^{* * *}$ & 0.089 & $0.330^{* * *}$ & 0.040 \\
\hline \multicolumn{7}{|c|}{ Lagged durable asset index: Reference Category: No durables } \\
\hline Asset poor $\left(1-33^{\text {th }}\right.$ percentile $)$ & 0.052 & 0.051 & 0.065 & 0.047 & 0.004 & 0.022 \\
\hline$\left(33^{\text {th }}-66^{\text {th }}\right.$ percentile $)$ & $0.171^{* * *}$ & 0.053 & $0.160^{* * *}$ & 0.052 & $0.167^{* * *}$ & 0.023 \\
\hline Asset rich $\left(66^{\text {th }}-100^{\text {th }}\right.$ percentile $)$ & $0.549^{* * *}$ & 0.070 & $0.467^{* * *}$ & 0.078 & $0.491^{* * *}$ & 0.028 \\
\hline Total pensions per capita & $0.020^{* *}$ & 0.009 & $0.022^{* * *}$ & 0.005 & $0.015^{* * *}$ & 0.003 \\
\hline \multicolumn{7}{|c|}{ Geography dummies: Reference Category: Katmandu } \\
\hline Rural west mount/hills & -0.106 & 0.107 & -0.026 & 0.138 & $0.195^{* * *}$ & 0.041 \\
\hline Rural eastern mount/hills & -0.064 & 0.136 & -0.240 & 0.184 & $0.241^{* * *}$ & 0.059 \\
\hline Rural western Terai & -0.094 & 0.124 & -0.198 & 0.142 & $0.114^{* *}$ & 0.048 \\
\hline Rural eastern Terai & 0.037 & 0.132 & -0.177 & 0.156 & $0.218^{* * *}$ & 0.053 \\
\hline Log of distance to market center & -0.073 & 0.124 & 0.008 & 0.152 & $0.299^{* * *}$ & 0.049 \\
\hline Ward level variables & & & & & & -0.024 \\
\hline$\%$ illiterate, among age $15+$ & -0.221 & 0.222 & -0.209 & 0.197 & $-0.369^{* * *}$ & 0.089 \\
\hline$\%$ literate or $1-4$ years of education & 0.054 & 0.309 & -0.300 & 0.291 & -0.115 & 0.136 \\
\hline$\%$ completed 5-7 years of education & 0.525 & 0.338 & -0.277 & 0.317 & $-0.603^{* * *}$ & 0.148 \\
\hline$\%$ employed in wage job & 0.098 & 0.273 & -0.037 & 0.188 & -0.117 & 0.098 \\
\hline$\%$ self employed & $-0.343^{* *}$ & 0.151 & -0.112 & 0.128 & $-0.223^{* * *}$ & 0.064 \\
\hline Log of average hh expenditure, 1995 & $0.146^{* *}$ & 0.073 & $0.208^{* * *}$ & 0.078 & $0.320^{* * *}$ & 0.032 \\
\hline Gini coefficient, 1995 & 0.324 & 0.304 & 0.243 & 0.256 & 0.052 & 0.144 \\
\hline Casualties from conflict, district level & $0.084^{*}$ & 0.043 & 0.030 & 0.030 & -0.010 & 0.014 \\
\hline Constant & -0.504 & 0.751 & $-1.514^{*}$ & 0.790 & $-2.783^{* * *}$ & 0.314 \\
\hline Number of observations & & & 3620 & & & \\
\hline Log-Likelihood & & & $-4,263$ & & & \\
\hline
\end{tabular}


Table A3.4: Full sample FIML estimation of the migration choice in the system (2-4).

\begin{tabular}{|c|c|c|c|c|}
\hline \multirow[t]{2}{*}{ Base category: No Migration } & \multicolumn{2}{|c|}{ Domestic Migration } & \multicolumn{2}{|c|}{ International Migration } \\
\hline & Coefficient & Std. Error & Coefficient & Std. Error \\
\hline Share of domestic migrants in district, 1995 & $1.015^{* * *}$ & 0.270 & -0.404 & 0.322 \\
\hline Share of international migrants in a ward, 2001 & 0.052 & 0.213 & $1.151^{* * *}$ & 0.184 \\
\hline \multicolumn{5}{|l|}{ Household Demographics (before migration) } \\
\hline Household size & $0.177^{* * *}$ & 0.016 & $0.142^{* * *}$ & 0.015 \\
\hline \multicolumn{5}{|l|}{ Share of children 0-3: Omitted variable } \\
\hline Share of children $4-7$ & -0.292 & 0.360 & 0.095 & 0.324 \\
\hline Share of children $8-15$ & -0.128 & 0.263 & -0.381 & 0.243 \\
\hline Share of men 16-64 & $1.181^{* * *}$ & 0.299 & 0.213 & 0.304 \\
\hline Share of women 16-64 & $1.953^{* * *}$ & 0.272 & $1.397^{* * *}$ & 0.259 \\
\hline Share of elderly & $1.898^{* * *}$ & 0.288 & 0.184 & 0.312 \\
\hline Number of married couples & $-0.398^{* * *}$ & 0.049 & $-0.096^{* *}$ & 0.047 \\
\hline Maximum education in the household & 0.001 & 0.024 & 0.031 & 0.024 \\
\hline \multicolumn{5}{|l|}{ Ethnicity: Reference Category: Brahman $\backslash$ Chhetri } \\
\hline Dalit & $-0.325^{* * *}$ & 0.114 & 0.003 & 0.097 \\
\hline Newar & $-0.208^{* *}$ & 0.102 & $-0.439^{* * *}$ & 0.121 \\
\hline Terai-Hill Janajatis & $-0.181^{* *}$ & 0.072 & -0.091 & 0.070 \\
\hline Muslim $\backslash$ Other Minorities & $-0.290^{* * *}$ & 0.082 & -0.090 & 0.078 \\
\hline \multicolumn{5}{|c|}{ Land holdings a year ago: Reference Category: No farm plot } \\
\hline Farm plot $<0.5$ ha & -0.060 & 0.075 & 0.023 & 0.075 \\
\hline Farm plot $0.5-1$ ha & $-0.226^{* *}$ & 0.092 & -0.108 & 0.089 \\
\hline Farm plot: $1-2$ ha & -0.135 & 0.102 & -0.042 & 0.100 \\
\hline Farm plot $>2$ ha & -0.103 & 0.127 & -0.203 & 0.129 \\
\hline \multicolumn{5}{|c|}{ Lagged durable asset index: Reference Category: No durables } \\
\hline Asset poor $\left(1-33^{\text {th }}\right.$ percentile $)$ & 0.055 & 0.071 & $-0.125^{*}$ & 0.070 \\
\hline$\left(33^{\text {th }}-66^{\text {th }}\right.$ percentile $)$ & -0.061 & 0.074 & $-0.157^{* *}$ & 0.073 \\
\hline Asset rich $\left(66^{\text {th }}-100^{\text {th }}\right.$ percentile $)$ & $-0.309^{* * *}$ & 0.093 & -0.118 & 0.089 \\
\hline Total pensions per capita & -0.014 & 0.010 & 0.011 & 0.007 \\
\hline \multicolumn{5}{|l|}{ Geography dummies: Reference Category: Katmandu } \\
\hline Other urban areas & $0.708^{* * *}$ & 0.140 & $0.546^{* * *}$ & 0.150 \\
\hline Rural west mount/hills & $0.601^{* * *}$ & 0.180 & $1.010^{* * *}$ & 0.187 \\
\hline Rural eastern mount/hills & $0.569^{* * *}$ & 0.166 & $0.447^{* *}$ & 0.180 \\
\hline Rural western Terai & $0.664^{* * *}$ & 0.177 & $0.715^{* * *}$ & 0.184 \\
\hline Rural eastern Terai & $0.836^{* * *}$ & 0.161 & $0.814^{* * *}$ & 0.171 \\
\hline Log of distance to market center & -0.030 & 0.026 & -0.017 & 0.025 \\
\hline \multicolumn{5}{|l|}{ Ward level variables } \\
\hline$\%$ illiterate, among age $15+$ & $-0.609^{* *}$ & 0.302 & 0.023 & 0.299 \\
\hline$\%$ literate or $1-4$ years of education & -0.674 & 0.444 & 0.447 & 0.431 \\
\hline$\%$ completed $5-7$ years of education & -0.045 & 0.489 & 0.425 & 0.481 \\
\hline$\%$ employed in wage job & -0.182 & 0.346 & 0.477 & 0.310 \\
\hline$\%$ self employed & $0.423^{* *}$ & 0.209 & 0.007 & 0.194 \\
\hline Log of average household expenditure, 1995 & 0.066 & 0.103 & 0.122 & 0.102 \\
\hline Gini coefficient, 1995 & -0.069 & 0.447 & $-0.926^{* *}$ & 0.423 \\
\hline Casualties from conflict, district level & -0.014 & 0.049 & -0.047 & 0.046 \\
\hline Constant & $-3.104^{* * *}$ & 1.008 & $-3.550^{* * *}$ & 0.995 \\
\hline Number of ob & & & & \\
\hline Log-Likelihood & & & & \\
\hline
\end{tabular}

Note: ${ }^{*}$ is significant at $10 \%$ level; ${ }^{* *}$ at $5 \%$ level; ${ }^{* * *}$ at $1 \%$ level; $;{ }^{*}$ indicates joint significance of coefficients at $10 \%$ level. 
Table A4.4: Full Sample FIML estimation of expenditure equations of the system (2-4)

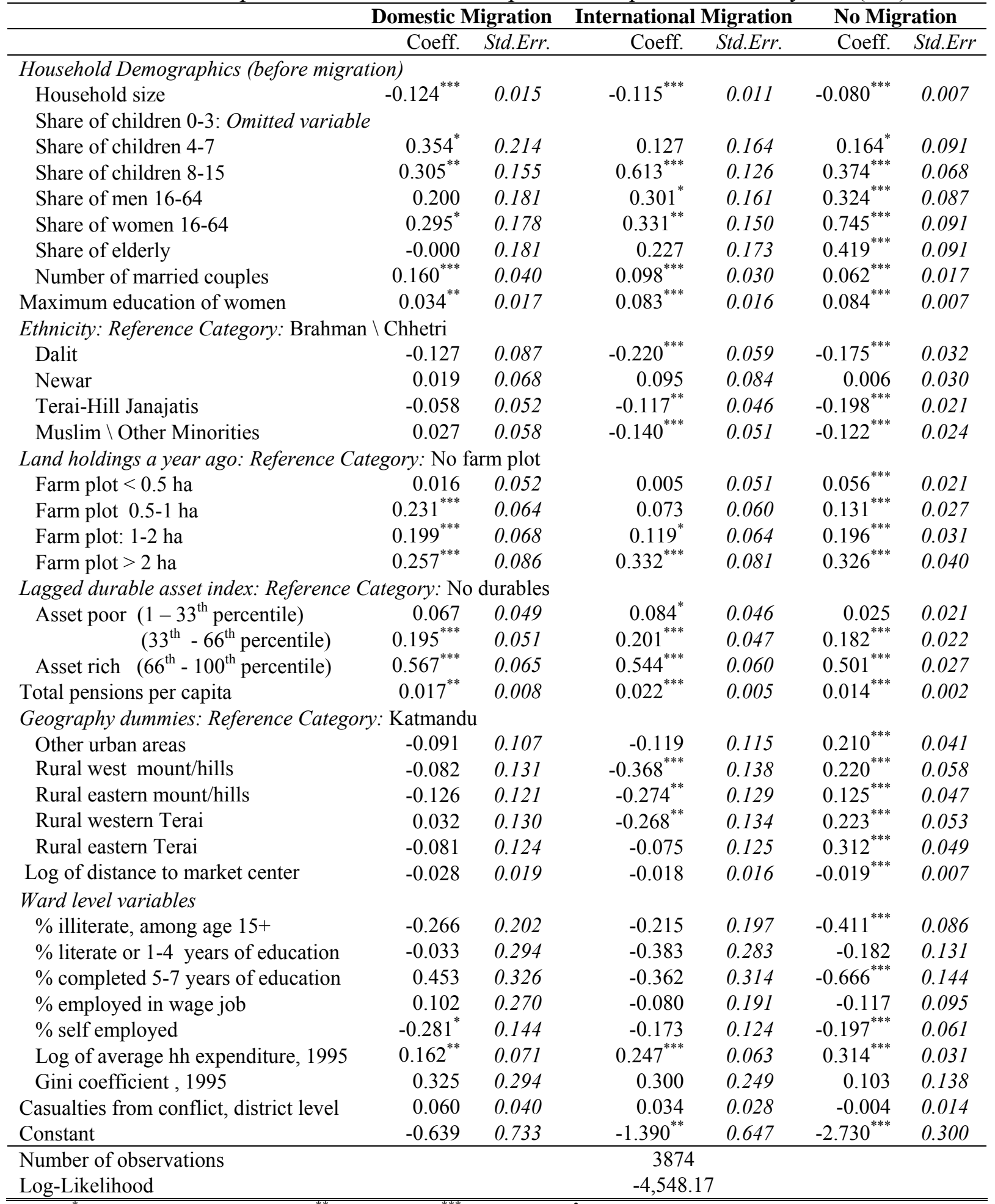

Note: ${ }^{*}$ is significant at $10 \%$ level; ${ }^{* *}$ at $5 \%$ level; ${ }^{* * *}$ at $1 \%$ level; ${ }^{*}$ indicates joint significance of coefficients at $10 \%$ level. 
Table A3.5: FIML estimation of the migration choice part of the system (2-4), where migration to India is treated as domestic migration.

\begin{tabular}{|c|c|c|c|c|}
\hline \multirow[t]{2}{*}{ Base category: No Migration } & \multicolumn{2}{|c|}{ Nepal + India Migration } & \multicolumn{2}{|c|}{ Other abroad Migration } \\
\hline & Coefficient & Std. Error & Coefficient & Std. Error \\
\hline Share of domestic migrants in district, 1995 & $0.620^{* *}$ & 0.279 & -0.214 & 0.465 \\
\hline Share of international migrants in a ward, 2001 & $0.664^{* * *}$ & 0.188 & $1.322^{* * *}$ & 0.249 \\
\hline \multicolumn{5}{|l|}{ Household Demographics (before migration) } \\
\hline Household size & $0.157^{* * *}$ & 0.014 & $0.119^{* * *}$ & 0.022 \\
\hline \multicolumn{5}{|l|}{ Share of children 0-3: Omitted variable } \\
\hline Share of children $4-7$ & -0.029 & 0.314 & 0.132 & 0.445 \\
\hline Share of children 8-15 & -0.151 & 0.231 & $-0.668^{*}$ & 0.341 \\
\hline Share of men $16-64$ & $0.919^{* * *}$ & 0.293 & -0.141 & 0.436 \\
\hline Share of women $16-64$ & $1.852^{* * *}$ & 0.247 & $1.276^{* * *}$ & 0.349 \\
\hline Share of elderly & $2.402^{* * *}$ & 0.312 & $1.267^{* * *}$ & 0.437 \\
\hline Number of married couples & $-0.265^{* * *}$ & 0.045 & $-0.145^{* *}$ & 0.064 \\
\hline Maximum education in the household & -0.011 & 0.023 & $0.105^{* * *}$ & 0.032 \\
\hline \multicolumn{5}{|l|}{ Ethnicity: Reference Category: Brahman $\backslash$ Chhetri } \\
\hline Dalit & -0.152 & 0.096 & 0.157 & 0.144 \\
\hline Newar & $-0.307^{* * *}$ & 0.102 & $-0.268^{*}$ & 0.143 \\
\hline Terai-Hill Janajatis & $-0.253^{* * *}$ & 0.067 & $0.211^{* *}$ & 0.092 \\
\hline Muslim $\backslash$ Other Minorities & $-0.202^{* * *}$ & 0.073 & -0.126 & 0.110 \\
\hline \multicolumn{5}{|c|}{ Land holdings a year ago: Reference Category: No farm plot } \\
\hline Farm plot $<0.5$ ha & 0.002 & 0.070 & -0.022 & 0.101 \\
\hline Farm plot $0.5-1$ ha & $-0.203^{* *}$ & 0.084 & -0.045 & 0.119 \\
\hline Farm plot: $1-2$ ha & -0.131 & 0.095 & 0.082 & 0.129 \\
\hline Farm plot $>2$ ha & $-0.239^{* *}$ & 0.122 & -0.010 & 0.156 \\
\hline \multicolumn{5}{|c|}{ Lagged durable asset index: Reference Category: No durables } \\
\hline Asset poor $\left(1-33^{\text {th }}\right.$ percentile $)$ & -0.016 & 0.064 & $-0.201^{*}$ & 0.109 \\
\hline$\left(33^{\text {th }}-66^{\text {th }}\right.$ percentile $)$ & $-0.123^{*}$ & 0.068 & 0.005 & 0.098 \\
\hline Asset rich $\left(66^{\text {th }}-100^{\text {th }}\right.$ percentile $)$ & $-0.383^{* * *}$ & 0.086 & 0.080 & 0.110 \\
\hline Total pensions per capita & $-0.026^{* *}$ & 0.012 & & \\
\hline \multicolumn{5}{|l|}{ Geography dummies: Reference Category: Katmandu } \\
\hline Other urban areas & $0.621^{* * *}$ & 0.136 & & \\
\hline Rural west mount/hills & $0.890^{* * *}$ & 0.171 & $0.721^{* * *}$ & 0.180 \\
\hline Rural eastern mount/hills & $0.495^{* * *}$ & 0.161 & $0.807^{* * *}$ & 0.235 \\
\hline Rural western Terai & $0.732^{* * *}$ & 0.167 & $0.794^{* * *}$ & 0.220 \\
\hline Rural eastern Terai & $0.736^{* * *}$ & 0.154 & $0.631^{* * *}$ & 0.242 \\
\hline Log of distance to market center & $-0.039^{*}$ & 0.024 & $1.180^{* * *}$ & 0.215 \\
\hline \multicolumn{5}{|l|}{ Ward level variables } \\
\hline$\%$ illiterate, among age $15+$ & -0.124 & 0.282 & -0.435 & 0.391 \\
\hline$\%$ literate or $1-4$ years of education & 0.009 & 0.412 & 0.441 & 0.570 \\
\hline$\%$ completed $5-7$ years of education & 0.099 & 0.455 & 0.267 & 0.633 \\
\hline$\%$ employed in wage job & 0.205 & 0.299 & 0.275 & 0.457 \\
\hline$\%$ self employed & $0.311^{*}$ & 0.186 & -0.178 & 0.276 \\
\hline Log of average hh expenditure, 1995 & -0.064 & 0.095 & $0.626^{* * *}$ & 0.152 \\
\hline Gini coefficient, 1995 & 0.010 & 0.400 & $-2.035^{* * *}$ & 0.631 \\
\hline Casualties from conflict, district level & -0.055 & 0.045 & 0.031 & 0.070 \\
\hline Constant & $-1.989^{* *}$ & 0.925 & $-8.038^{* * *}$ & 1.460 \\
\hline Number of obser & & & & \\
\hline Log-Likelihood & & & & \\
\hline
\end{tabular}

Note: ${ }^{*}$ is significant at $10 \%$ level; ${ }^{* *}$ at $5 \%$ level; ${ }^{* * *}$ at $1 \%$ level; ${ }^{*}$ indicates joint significance of coefficients at $10 \%$ level. 
Table A4.5: FIML estimation of expenditure equations of the system (2-4), where India is treated as domestic destination

\begin{tabular}{|c|c|c|c|c|c|c|}
\hline & \multicolumn{2}{|c|}{ Domestic Migration } & \multicolumn{2}{|c|}{ International Migration } & \multicolumn{2}{|c|}{ No Migration } \\
\hline & Coeff. & Std.Err. & Coeff. & Std.Err. & Coeff. & Std.Err \\
\hline \multicolumn{7}{|c|}{ Household Demographics (before migration) } \\
\hline Household size & $-0.109^{* * *}$ & 0.012 & $-0.084^{* * *}$ & 0.018 & $-0.071^{* * *}$ & 0.008 \\
\hline \multicolumn{7}{|l|}{ Share of children 0-3: Omitted variable } \\
\hline Share of children 4-7 & 0.238 & 0.155 & 0.059 & 0.249 & $0.167^{*}$ & 0.092 \\
\hline Share of children 8-15 & $0.486^{* * *}$ & 0.113 & $0.465^{* *}$ & 0.218 & $0.370^{* * *}$ & 0.070 \\
\hline Share of men 16-64 & $0.326^{* *}$ & 0.145 & $0.469^{*}$ & 0.269 & $0.274^{* * *}$ & 0.095 \\
\hline Share of women 16-64 & $0.511^{* * *}$ & 0.144 & $0.506^{* *}$ & 0.229 & $0.796^{* * *}$ & 0.104 \\
\hline Share of elderly & 0.146 & 0.164 & 0.402 & 0.263 & $0.371^{* * *}$ & 0.139 \\
\hline Number of married couples & $0.102^{* * *}$ & 0.028 & 0.038 & 0.049 & $0.054^{* * *}$ & 0.018 \\
\hline Maximum education of women & $0.061^{* * *}$ & 0.013 & $0.055^{* *}$ & 0.025 & $0.085^{* * *}$ & 0.008 \\
\hline \multicolumn{7}{|c|}{ Ethnicity: Reference Category: Brahman $\backslash$ Chhetri } \\
\hline Dalit & $-0.239^{* * *}$ & 0.055 & -0.074 & 0.106 & $-0.183^{* * *}$ & 0.033 \\
\hline Newar & 0.081 & 0.067 & -0.068 & 0.110 & -0.001 & 0.032 \\
\hline Terai-Hill Janajatis & -0.047 & 0.044 & $-0.166^{* *}$ & 0.074 & $-0.224^{* * *}$ & 0.024 \\
\hline Muslim $\backslash$ Other Minorities & $-0.082^{*}$ & 0.044 & 0.015 & 0.087 & $-0.137^{* * *}$ & 0.025 \\
\hline \multicolumn{7}{|c|}{ Land holdings a year ago: Reference Category: No farm plot } \\
\hline Farm plot $<0.5$ ha & -0.014 & 0.043 & -0.061 & 0.076 & $0.059^{* * *}$ & 0.022 \\
\hline Farm plot $0.5-1$ ha & $0.135^{* * *}$ & 0.052 & $-0.174^{*}$ & 0.089 & $0.135^{* * *}$ & 0.028 \\
\hline Farm plot: $1-2$ ha & $0.147^{* * *}$ & 0.056 & -0.003 & 0.092 & $0.198^{* * *}$ & 0.032 \\
\hline Farm plot $>2$ ha & $0.289^{* * *}$ & 0.073 & 0.119 & 0.107 & $0.326^{* * *}$ & 0.040 \\
\hline \multicolumn{7}{|c|}{ Lagged durable asset index: Reference Category: No durables } \\
\hline Asset poor $\left(1-33^{\text {th }}\right.$ percentile $)$ & $0.076^{* *}$ & 0.037 & 0.104 & 0.089 & 0.010 & 0.022 \\
\hline$\left(33^{\text {th }}-66^{\text {th }}\right.$ percentile $)$ & $0.186^{* * *}$ & 0.040 & $0.158^{* *}$ & 0.070 & $0.166^{* * *}$ & 0.023 \\
\hline Asset rich $\left(66^{\text {th }}-100^{\text {th }}\right.$ percentile $)$ & $0.588^{* * *}$ & 0.057 & $0.344^{* * *}$ & 0.079 & $0.478^{* * *}$ & 0.030 \\
\hline Total pensions per capita & $0.025^{* * *}$ & 0.008 & $0.013^{* *}$ & 0.006 & $0.013^{* * *}$ & 0.003 \\
\hline \multicolumn{7}{|c|}{ Geography dummies: Reference Category: Katmandu } \\
\hline Other urban areas & 0.019 & 0.099 & -0.015 & 0.151 & $0.204^{* * *}$ & 0.046 \\
\hline Rural west mount/hills & -0.161 & 0.122 & -0.177 & 0.191 & $0.230^{* * *}$ & 0.064 \\
\hline Rural eastern mount/hills & -0.048 & 0.108 & -0.233 & 0.176 & $0.120^{* *}$ & 0.052 \\
\hline Rural western Terai & -0.006 & 0.115 & -0.104 & 0.194 & $0.223^{* * *}$ & 0.056 \\
\hline Rural eastern Terai & 0.074 & 0.110 & -0.069 & 0.188 & $0.306^{* * *}$ & 0.057 \\
\hline Log of distance to market center & -0.021 & 0.014 & -0.035 & 0.025 & $-0.025^{* * *}$ & 0.008 \\
\hline \multicolumn{7}{|l|}{ Ward level variables } \\
\hline$\%$ illiterate, among age $15+$ & $-0.358^{* *}$ & 0.165 & 0.044 & 0.273 & $-0.384^{* * *}$ & 0.088 \\
\hline$\%$ literate or $1-4$ years of education & -0.287 & 0.235 & -0.047 & 0.409 & -0.143 & 0.135 \\
\hline$\%$ completed 5-7 years of education & 0.156 & 0.267 & -0.671 & 0.441 & $-0.629^{* * *}$ & 0.146 \\
\hline$\%$ employed in wage job & 0.014 & 0.174 & -0.148 & 0.361 & -0.129 & 0.096 \\
\hline$\%$ self employed & -0.140 & 0.108 & -0.177 & 0.202 & $-0.199^{* * *}$ & 0.063 \\
\hline Log of average hh expenditure, 1995 & $0.237^{* * *}$ & 0.053 & 0.189 & 0.144 & $0.314^{* * *}$ & 0.036 \\
\hline Gini coefficient, 1995 & -0.020 & 0.212 & $1.032^{* *}$ & 0.496 & 0.082 & 0.153 \\
\hline Casualties from conflict, district level & $0.045^{*}$ & 0.027 & 0.001 & 0.057 & -0.008 & 0.014 \\
\hline Constant & $-1.422^{* *}$ & 0.566 & -1.035 & 1.461 & $-2.739^{* * *}$ & 0.342 \\
\hline Number of observations & & & 3620 & & & \\
\hline Log-Likelihood & & & $-4,061$ & & & \\
\hline
\end{tabular}

Note: ${ }^{*}$ is significant at $10 \%$ level; ${ }^{* *}$ at $5 \%$ level; ${ }^{* * *}$ at $1 \%$ level; ${ }^{*}$ indicates joint significance of coefficients at $10 \%$ level. 
Table A3.6: FIML estimation of the migration choice part of the system (2-4), assuming equal returns in earning equations.

\begin{tabular}{|c|c|c|c|c|}
\hline \multirow[t]{2}{*}{ Base category: No Migration } & \multicolumn{2}{|c|}{ Domestic Migration } & \multicolumn{2}{|c|}{ International Migration } \\
\hline & Coefficient & Std. Error & Coefficient & Std. Error \\
\hline Share of domestic migrants in district, 1995 & $0.902^{* * *}$ & 0.318 & -0.465 & 0.335 \\
\hline Share of international migrants in a ward, 2001 & 0.061 & 0.232 & $1.128^{* * *}$ & 0.193 \\
\hline \multicolumn{5}{|l|}{ Household Demographics (before migration) } \\
\hline Household size & $0.159^{* * *}$ & 0.017 & $0.131^{* * *}$ & 0.015 \\
\hline \multicolumn{5}{|l|}{ Share of children 0-3: Omitted variable } \\
\hline Share of children $4-7$ & -0.224 & 0.370 & 0.147 & 0.321 \\
\hline Share of children 8-15 & -0.062 & 0.271 & $-0.489^{* *}$ & 0.242 \\
\hline Share of men $16-64$ & $1.032^{* * *}$ & 0.329 & 0.155 & 0.319 \\
\hline Share of women $16-64$ & $2.046^{* * *}$ & 0.283 & $1.286^{* * *}$ & 0.261 \\
\hline Share of elderly & $2.965^{* * *}$ & 0.346 & $0.975^{* * *}$ & 0.348 \\
\hline Number of married couples & $-0.380^{* * *}$ & 0.051 & $-0.096^{* *}$ & 0.048 \\
\hline Maximum education in the household & 0.001 & 0.026 & 0.011 & 0.025 \\
\hline \multicolumn{5}{|l|}{ Ethnicity: Reference Category: Brahman $\backslash$ Chhetri } \\
\hline Dalit & $-0.294^{* *}$ & 0.120 & 0.014 & 0.097 \\
\hline Newar & $-0.242^{* *}$ & 0.107 & $-0.443^{* * *}$ & 0.121 \\
\hline Terai-Hill Janajatis & $-0.177^{* *}$ & 0.075 & $-0.139^{* *}$ & 0.070 \\
\hline Muslim $\backslash$ Other Minorities & $-0.287^{* * *}$ & 0.086 & -0.092 & 0.078 \\
\hline \multicolumn{5}{|c|}{ Land holdings a year ago: Reference Category: No farm plot } \\
\hline Farm plot $<0.5$ ha & -0.060 & 0.078 & 0.047 & 0.075 \\
\hline Farm plot $0.5-1$ ha & $-0.241^{* *}$ & 0.096 & -0.070 & 0.089 \\
\hline Farm plot: $1-2$ ha & -0.135 & 0.107 & 0.000 & 0.099 \\
\hline Farm plot $>2$ ha & -0.140 & 0.132 & -0.168 & 0.128 \\
\hline \multicolumn{5}{|c|}{ Lagged durable asset index: Reference Category: No durables } \\
\hline Asset poor $\left(1-33^{\text {th }}\right.$ percentile $)$ & 0.062 & 0.073 & $-0.142^{* *}$ & 0.069 \\
\hline$\left(33^{\text {th }}-66^{\text {th }}\right.$ percentile $)$ & -0.043 & 0.077 & $-0.123^{*}$ & 0.072 \\
\hline Asset rich $\left(66^{\text {th }}-100^{\text {th }}\right.$ percentile $)$ & $-0.311^{* * *}$ & 0.096 & -0.122 & 0.088 \\
\hline Total pensions per capita & -0.014 & 0.012 & 0.013 & 0.008 \\
\hline \multicolumn{5}{|l|}{ Geography dummies: Reference Category: Katmandu } \\
\hline Other urban areas & $0.710^{* * *}$ & 0.146 & $0.577^{* * *}$ & 0.152 \\
\hline Rural west mount/hills & $0.585^{* * *}$ & 0.189 & $1.114^{* * *}$ & 0.188 \\
\hline Rural eastern mount/hills & $0.571^{* * *}$ & 0.173 & $0.525^{* * *}$ & 0.180 \\
\hline Rural western Terai & $0.667^{* * *}$ & 0.183 & $0.793^{* * *}$ & 0.185 \\
\hline Rural eastern Terai & $0.822^{* * *}$ & 0.167 & $0.854^{* * *}$ & 0.171 \\
\hline Log of distance to market center & -0.044 & 0.027 & -0.017 & 0.025 \\
\hline \multicolumn{5}{|l|}{ Ward level variables } \\
\hline$\%$ illiterate, among age $15+$ & -0.499 & 0.315 & -0.020 & 0.299 \\
\hline$\%$ literate or $1-4$ years of education & -0.420 & 0.464 & 0.542 & 0.438 \\
\hline$\%$ completed 5-7 years of education & -0.146 & 0.520 & 0.300 & 0.482 \\
\hline$\%$ employed in wage job & -0.084 & 0.358 & 0.419 & 0.305 \\
\hline$\%$ self employed & $0.542^{* *}$ & 0.216 & -0.042 & 0.193 \\
\hline Log of average hh expenditure, 1995 & 0.075 & 0.109 & 0.151 & 0.102 \\
\hline Gini coefficient, 1995 & 0.028 & 0.466 & $-0.913^{* *}$ & 0.422 \\
\hline Casualties from conflict, district level & -0.022 & 0.052 & -0.042 & 0.046 \\
\hline Constant & $-3.284^{* * *}$ & 1.061 & $-3.685^{* * *}$ & 0.994 \\
\hline Number of obse & & & & \\
\hline Log-Likelihood & & & & \\
\hline
\end{tabular}

Note: ${ }^{*}$ is significant at $10 \%$ level; ${ }^{* *}$ at $5 \%$ level; ${ }^{* * *}$ at $1 \%$ level; ${ }^{*}$ indicates joint significance of coefficients at $10 \%$ level. 
Table A4.6: FIML estimation of expenditure equations of the system (2-4), assuming equal returns in earning equations.

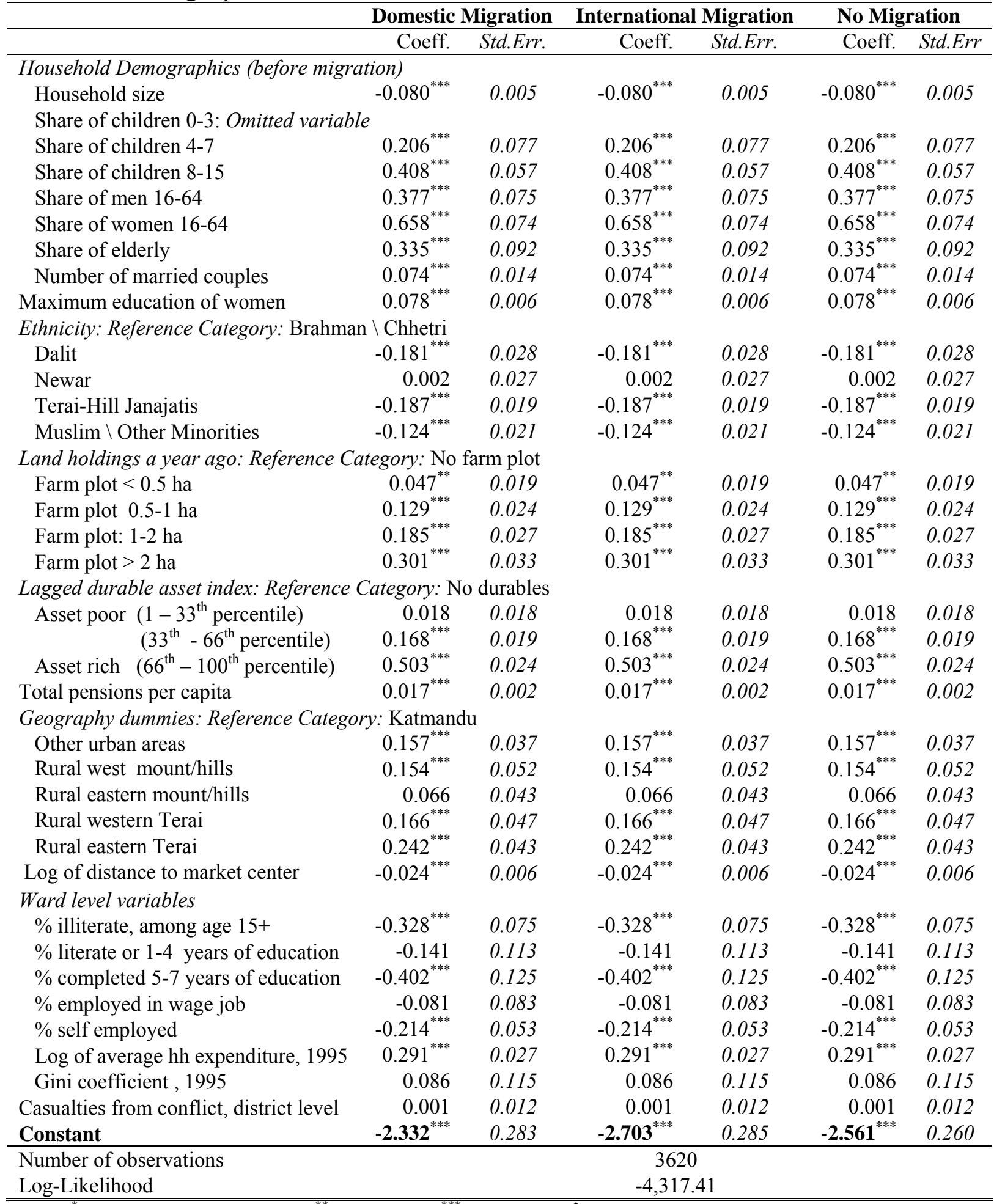

Note: ${ }^{*}$ is significant at $10 \%$ level; ${ }^{* *}$ at $5 \%$ level; ${ }^{* * *}$ at $1 \%$ level; ${ }^{*}$ indicates joint significance of coefficients at $10 \%$ level. 
Table A5: Simulated changes in expenditure, poverty and inequality rates for different migration scenarios (standard errors in parenthesis).

\begin{tabular}{|c|c|c|c|c|c|}
\hline Migration scenarios & Actual & $\begin{array}{c}\text { No } \\
\text { migration }\end{array}$ & $\begin{array}{c}\text { Level of } \\
\text { migration } \\
\text { as in 1995-96 }\end{array}$ & $\begin{array}{c}+10 \% \text { point } \\
\text { increase in } \\
\text { domestic } \\
\text { migration }\end{array}$ & $\begin{array}{c}+10 \% \text { point } \\
\text { increase in } \\
\text { international } \\
\text { migration }\end{array}$ \\
\hline Household types & \multicolumn{5}{|c|}{ Poverty rate (changes in percentage points) } \\
\hline All Households & 30.0 & $\begin{array}{l}+3.6^{*} \\
(2.1)\end{array}$ & $\begin{array}{l}+1.8^{*} \\
(0.9)\end{array}$ & $\begin{array}{l}-2.4^{*} \\
(1.3)\end{array}$ & $\begin{array}{l}-0.5 \\
(1.1)\end{array}$ \\
\hline $\begin{array}{l}\text { Households with no } \\
\text { migrants }\end{array}$ & 30.6 & 0 & 0 & $\begin{array}{l}-3^{*} \\
(1.4)\end{array}$ & $\begin{array}{l}-1.3 \\
(1.9)\end{array}$ \\
\hline $\begin{array}{l}\text { Households with } \\
\text { migrants within Nepal }\end{array}$ & 22.9 & $\begin{array}{r}+23.4^{*} \\
(9.4)\end{array}$ & $\begin{array}{l}+7.1^{*} \\
(3.6)\end{array}$ & 0 & $\begin{array}{l}+2.6 \\
(2.8)\end{array}$ \\
\hline \multirow[t]{2}{*}{$\begin{array}{l}\text { Households with } \\
\text { migrants abroad }\end{array}$} & 32.8 & $\begin{array}{l}+2.1 \\
(7.3) \\
\end{array}$ & $\begin{array}{l}+4.4 \\
(4.2) \\
\end{array}$ & $\begin{array}{l}-2.1 \\
(2.5)\end{array}$ & 0 \\
\hline & \multicolumn{5}{|c|}{ Average expenditure, $N R P 10,000$ 's } \\
\hline All Households & 1.493 & $\begin{array}{l}-0.088^{*} \\
(0.046)\end{array}$ & $\begin{array}{l}-0.047^{*} \\
(0.022)\end{array}$ & $\begin{array}{l}+0.068^{*} \\
(0.041)\end{array}$ & $\begin{array}{l}+0.022 \\
(0.037)\end{array}$ \\
\hline $\begin{array}{l}\text { Households with no } \\
\text { migrants }\end{array}$ & 1.493 & 0 & 0 & $\begin{array}{c}+0.092^{*} \\
(0.050)\end{array}$ & $\begin{array}{l}+0.043 \\
(0.061)\end{array}$ \\
\hline $\begin{array}{l}\text { Households with } \\
\text { migrants within Nepal }\end{array}$ & 1.576 & $\begin{array}{l}-0.489^{*} \\
(0.188)\end{array}$ & $\begin{array}{l}-0.175^{*} \\
(0.079)\end{array}$ & 0 & $\begin{array}{l}-0.049 \\
(0.060)\end{array}$ \\
\hline \multirow[t]{2}{*}{$\begin{array}{l}\text { Households with } \\
\text { migrants abroad }\end{array}$} & 1.441 & $\begin{array}{c}-0.1 \\
(0.177) \\
\end{array}$ & $\begin{array}{l}-0.113 \\
(0.100)\end{array}$ & $\begin{array}{l}+0.037 \\
(0.080)\end{array}$ & 0 \\
\hline & \multicolumn{5}{|c|}{ Inequality rate (Gini) } \\
\hline All Households & 0.409 & $\begin{array}{l}-0.004 \\
(0.004)\end{array}$ & $\begin{array}{l}-0.002 \\
(0.004)\end{array}$ & $\begin{array}{l}+0.003 \\
(0.005)\end{array}$ & $\begin{array}{l}+0.003 \\
(0.004)\end{array}$ \\
\hline
\end{tabular}

